\title{
MINERALOGY AND ORIGIN OF SPOTS IN SPOTTED SLATE FROM THE MALÁGUIDE COMPLEX, BETIC CORDILLERAS, SPAIN: AN XRD, EMPA AND TEM-AEM STUDY
}

\author{
MARÍA DOLORES RUIZ CRUZ ${ }^{\S}$ \\ Departamento de Química Inorgánica, Cristalografía y Mineralogía, Facultad de Ciencias, \\ Universidad de Málaga, E-29071 Málaga, Spain \\ EMILIO GALÁN \\ Departamento de Cristalografía, Mineralogía y Química Agrícola, Facultad de Química, \\ Universidad de Sevilla, E-41071 Sevilla, Spain
}

\begin{abstract}
We have studied the nature of spots occurring in spotted slates from the Maláguide Complex, in the Betic Cordilleras of southern Spain, by optical microscopy, X-ray diffraction, electron-microprobe analysis and transmission electron microscopy. These spots developed during an episode of contact metamorphism after the Alpine regional event. They are optically and mineralogically zoned, the extent of the zones being dependent upon both the composition of the slates (or of the different bands in these) and the degree of spot development. The mineral zonation is clearly correlated with the chemical variations, as revealed by electron-microprobe analyses obtained across the spots. In the best-developed spots, an inner isotropic zone, characterized by $\mathrm{Al}$ enrichment relative to the slate, is followed by an intermediate quartz- or mica-rich zone showing a relative enrichment in either $\mathrm{Si}$ or in $\mathrm{Si}, \mathrm{K}$, and $\mathrm{Na}$; an outer yellow to reddish zone shows a notable increase in Fe. TEM-AEM studies indicate that the innermost isotropic zone mainly consists of "amorphous" $\mathrm{Si}-\mathrm{Al}$ or $\mathrm{Si}-\mathrm{Al}-\mathrm{Fe}$ phases that contain numerous phyllosilicate inclusions. Two main phyllosilicate associations have been identified in the spots: muscovite + berthierine \pm chlorite and muscovite + biotite + chlorite. The first assemblage is characterized by the development of Al-poor oxidized berthierine, which preferentially developed in Fe-rich spots, whereas the second association is better developed in micaceous spots. Even where both assemblages coexist in a single spot, they are restricted to different microdomains. Textural features indicate that berthierine formed as a product of the reaction of both chlorite and muscovite. The first transformation occurred through disordered polytypes of chlorite and involved a notable $\mathrm{Fe}$ enrichment relative to the original chlorite. In contrast, formation of berthierine from muscovite occurred through a complex set of muscovite-berthierine interstratifications and intergrowths. AEM data for biotite and berthierine suggest that the availability of Fe may be an important factor controlling the formation of berthierine in spotted slate in the Maláguide complex.
\end{abstract}

Keywords: berthierine, biotite, chlorite, muscovite, X-ray diffraction, electron-microprobe analysis, transmission electron microscopy, analytical electron microscopy, Maláguide complex, Betic Cordilleras, Spain.

\section{SOMMAIRE}

Nous avons étudié la nature des taches dans l'ardoise tachetée du complexe de Maláguide, Cordillères Bétiques du sud de l'Espagne, au moyen de la microscopie optique, de la diffraction X, des analyses à la microsonde électronique, et de la microscopie électronique par transmission. Ces taches se sont dévelopées au cours d'un épisode de métamorphisme de contact suite au métamorphisme alpin. Elles sont zonées optiquement et minéralogiquement. Le développement de ces zones dépend à la fois de la composition de l'ardoise (ou de ses différentes couches) et du degré de développement des taches. La zonation minéralogique montre une corrélation avec les variations en composition, selon les prélèvements à la microsonde électronique le long de traverses d'une bordure à l'autre des taches. Dans les taches les mieux développées, une zone isotrope intérieure montre un enrichissement en Al par rapport à l'ardoise; cette zone est entourée d'une zone intermédiaire riche en quartz ou en mica, et enrichie en Si ou en $\mathrm{Si}, \mathrm{K}$, et $\mathrm{Na}$; une zone externe jaune à rougeâtre fait preuve d'un enrichissement important en Fe. Les observations effectuée au microscope électronique avec facilités analytiques montrent que la zone interne contient surtout des phases "amorphes" à Si-Al ou à $\mathrm{Si}-\mathrm{Al}-\mathrm{Fe}$ contenant une abondance d'inclusions phyllosilicatées. Nous documentons deux associations principales de phyllosilicates dans les taches: muscovite + berthierine \pm chlorite et muscovite + biotite + chlorite. Dans le premier assemblage,

§E-mail address: mdruiz@uma.es 
la berthierine, oxydée et pauvre en Al, s'est développée de préférence aux endroits montrant un enrichissement en fer, tandis que la seconde association est mieux développée dans les taches micacées. Même dans les cas où les deux associations coexistent dans une même tache, elles occupent des microdomaines différents. Selon les relations texturales, la berthierine se serait formée aux dépens de soit la chlorite, soit la muscovite. La première transformation a progressée par le développement de polytypes désordonnés de la chlorite lors d'un enrichissement marqué en fer par rapport à la chlorite originelle. En revanche, la formation de la berthierine aux dépens de la muscovite s'est déroulée grâce à un assemblage complexe d'interstratifiés et d'intercroissances muscovite-berthierine. D'après les données analytiques sur la biotite et la berthierine prélevées au microscope électronique, la disponibilité de fer serait un facteur important dans la formation de la berthierine dans l'ardoise tachetée du complexe Maláguide.

(Traduit par la Rédaction)

Mots-clés: berthierine, biotite, chlorite, muscovite, diffraction $\mathrm{X}$, analyses à la microsonde électronique, microscopie électronique par transmission, microscopie électronique analytique, complexe Maláguide, Cordillères Bétiques, Espagne.

\section{INTRODUCTION}

The spotted or knotted texture is a distinctive feature typical of low-grade contact-metamorphosed pelites (e.g., Harker 1939, Kerrick 1990). This texture is produced in most cases (but not all: see below) by subhedral crystals of andalusite or cordierite (or both) that overprint the pre-existing foliation. In many cases, the only change observed is the development of $\mathrm{mm}$-sized ovoid spots consisting of aggregates of muscovite and chlorite that are interpreted to be the result of the alteration of cordierite crystals (Pattison \& Tracy 1991). Moreover, the outermost zone of the contact aureoles developed in pelitic rocks is characterized by the occurrence of biotite together with muscovite and chlorite (Miyashiro 1994), and these aggregates of phyllosilicates are then interpreted as the first product of the metamorphic reactions at low temperature.

In metaclastites from the Maláguide Complex (Betic Cordilleras, Spain), the assemblage muscovite + chlorite is widespread. Moreover, chlorite-bearing mixedlayers and vermiculite have also been described (Ruiz Cruz 1999, 2001) and interpreted as having being formed from chlorite during the prograde Alpine metamorphic event. This study focuses on the development of spotted slate in restricted areas of this Complex. From a previous study of ten samples of spotted slate, three samples showing a different degree of spot development were selected for a detailed study, using X-ray diffraction (XRD), electron-microprobe analysis (EMPA), and transmission electron microscopy with analytical capability (TEM-AEM).

The aim of this study is to determine both the structural and the chemical changes associated with spot formation. These data may supply important information about the stability relationships between chlorite and berthierine, as well as about the origin of these aggregates of phyllosilicates.

\section{BACKGROUND INFORMATION}

In the zone below the biotite isograd, textural modifications are subtle. Furthermore, the fine-grained as- semblages are very difficult to analyze with an electron microprobe. As a result, most of the sequences of model reactions in contact metamorphism concentrate on assemblages beyond the first appearance of biotite. Nevertheless, reactions described in low-grade metapelites may be applied to both contact and regional metamorphic settings (Pattison \& Tracy 1991).

The most common biotite-forming reactions in lowgrade metapelites involve chlorite and a K-rich phase (Guidotti 1984, Frey 1987, Bucher \& Frey 1994):

$$
\begin{aligned}
& \text { Chlorite }+ \text { Potassium Feldspar }=\text { Biotite }+ \\
& \text { Muscovite }+ \text { Quartz }+\mathrm{H}_{2} \mathrm{O} \\
& \text { Phengite }+ \text { Chlorite }=\text { Biotite }+ \text { Muscovite }+ \\
& \text { Quartz }+\mathrm{H}_{2} \mathrm{O}
\end{aligned}
$$

In contact aureoles, biotite commonly forms from chlorite and muscovite via the following reactions, which account for andalusite or cordierite (or both) (Yardley 1989, Pattison \& Tracy 1991):

$$
\begin{aligned}
& \text { Muscovite }+ \text { Chlorite }+ \text { Quartz }=\text { Cordierite }+ \\
& \text { Biotite }+\mathrm{H}_{2} \mathrm{O} \\
& \text { Muscovite }+ \text { Chlorite }=\text { Andesine }+ \text { Biotite }+ \\
& \text { Quartz }+\mathrm{H}_{2} \mathrm{O}
\end{aligned}
$$$$
\text { Muscovite }+ \text { Chlorite }+ \text { Quartz }=\text { Cordierite }+
$$$$
\text { Andalusite }+ \text { Biotite }+\mathrm{H}_{2} \mathrm{O}
$$

Although the assemblage muscovite + chlorite + biotite is common in both contact and regional low-grade rocks, the association muscovite-berthierine has not been previously reported in this context. In fact, berthierine has generally been described in sedimentary iron-formations (Iijima \& Matsumoto 1982, Toth \& Fritz 1997), and has commonly been considered as the low-temperature variety of chlorite, the evolution of which during diagenesis and progressive metamorphism leads to magnesian chamosite (Velde 1973, Kisch 1983, Curtis et al. 1985, Weaver 1989, Walker \& Thompson 1990). Berthierine has also been identified as a product 
of the retrograde alteration of Fe-bearing phases such as cordierite (Abad-Ortega \& Nieto 1995) and chloritoid (Banfield et al. 1989), and the possibility that berthierine may form during a hydrothermal or metamorphic process has been pointed out by Slack et al. (1992) and Jiang et al. (1992). On the other hand, the persistence of berthierine, partially transformed into chlorite, in metapelites metamorphosed to the prehnite-pumpellyite facies (Coombs et al. 2000) and in rocks of the granulite facies (Xu \& Veblen 1996) lends support to the possibility of a stability field for berthierine, that over- laps that of chlorite with a somewhat similar composition.

\section{Geological Setting}

The Maláguide Complex forms part of the Internal zones of the Betic Cordilleras in southern Spain (Fig. 1). Three main tectonic Complexes have been distinguished within the Internal zones; from bottom to top, and in order of decreasing metamorphic grade, these are: Nevado-Filábride, Alpujárride, and Maláguide.

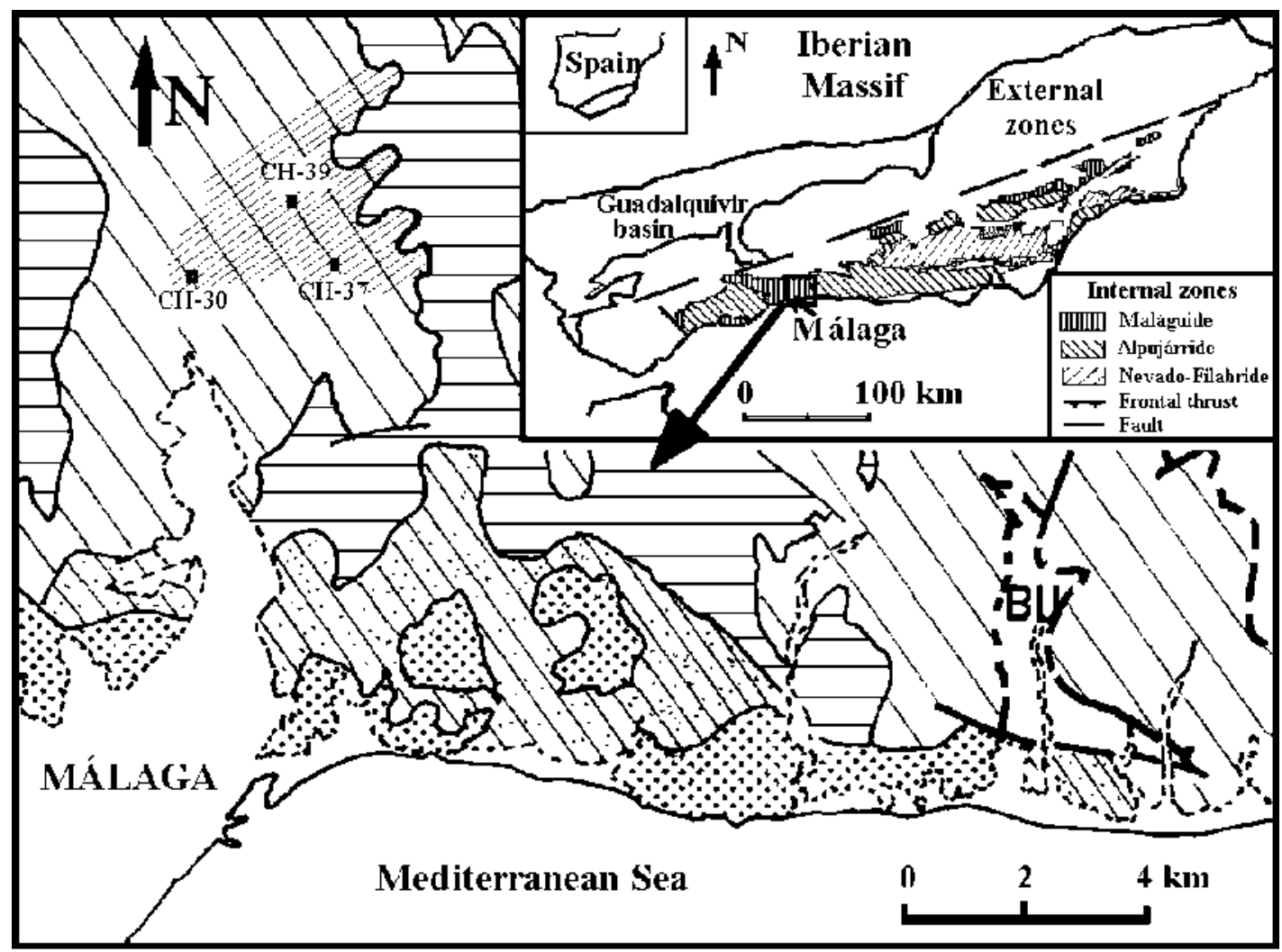

Postorogenic materials

$\because$ Permo-Triassic Unit

\section{Palaeozoic Lnits}

Greywacke-shale member

"Calizas alabeadas" member"

\section{Phyllite member}

\section{B.U. Benamocarra Unit}

FIG. 1. Geological sketch of the Maláguide Complex in the Málaga area, southern Spain, and location of the samples studied. The spotted slates have been identified in the shaded area. Inset: position of the study area in the Betic Cordilleras. 
The zone studied comprises the most important exposure of the Maláguide suite, located near Málaga (Fig. 1). The Paleozoic sequence of the Maláguide Complex in the Málaga area comprises three members (Mäkel 1985): a) the phyllite member; b) the "calizas alabeadas" member, and c) the greywacke-shale member. Variably colored phyllitic rocks form the basal part of the Paleozoic. The overlying sequence comprises limestone with intercalated shale and greywackes. The bulk of the Paleozoic Unit is made up of rocks of the greywacke-shale member, consisting of a rhythmic alternation of greywacke, shale and siltstone. Tectonic features (Mäkel 1985) and petrological data (Ruiz Cruz 1997, Ruiz Cruz \& Andreo 1996a) indicate that both the Variscan and the Alpine orogenies affected this Complex. Temperatures deduced from variations in chlorite composition (Ruiz Cruz 1997) are in the order of $300^{\circ} \mathrm{C}$ during the Variscan event, whereas the range of $150^{\circ} \mathrm{C}->300^{\circ} \mathrm{C}$ was identified in Alpine chlorites.

On the basis of the illite "crystallinity" (IC) and chlorite "crystallinity" (CC) indices, three zones, diagenetic, anchizone and epizone, have been documented in the study area, which approximately correspond to the Permo-Triassic, the Carboniferous-Devonian and the Silurian-Ordovician sequences (Ruiz Cruz \& Rodríguez Jiménez 2002). The oldest sequence (or phyllite member) (Mäkel 1985) is also characterized by the presence of numerous mafic dikes, more abundant in the lower part of the sequence. The dikes are considered to represent the remains of one of the earliest magmatic episodes within the Neogene volcanic province that is associated with the late orogenic evolution of the Alboran region (Torres Roldán et al. 1986).

The monotonous assemblage quartz - albite - muscovite - chlorite is the most widespread in the Maláguide rocks. Moreover, the local development of other phyllosilicate and non-phyllosilicate phases has permitted the determination of a detailed metamorphic zonation (Ruiz Cruz \& Rodriguez Jiménez 2002). In Al-rich graywackes from the Permo-Triassic and Carboniferous sequences, the evolutionary sequence kaolinite $\rightarrow$ dickite $\rightarrow$ nacrite has been identified (Ruiz Cruz 1996, Ruiz Cruz \& Andreo 1996a), which locally evolves toward tosudite (Ruiz Cruz \& Andreo 1996b). Throughout the Paleozoic sequence, reactions involving chlorite have led to the following sequence of minerals, with increasing metamorphic grade: mica-chlorite mixedlayers $\rightarrow$ chlorite-vermiculite mixed-layers $\rightarrow$ vermiculite (Ruiz Cruz 1999, 2001). The development of other metamorphic minerals, mainly chloritoid, paragonite, andalusite and garnet, is restricted to the southeastern part of the area studied, near the boundary with the Benamocarra unit, which is considered to be transitional between the Maláguide and the Alpujárride Complexes.

Because of the thinness of the dikes $(<1 \mathrm{~m})$, their contact-metamorphic effect on the enclosing slates cannot be identified in most of the Maláguide rocks. Nevertheless, spotted slates with textural features char- acteristic of an external aureole zone appear in the studied area, although at the moment, this metamorphic effect on the enclosing slates has been identified in a restricted zone only (Fig. 1).

\section{SAMPLES ANd EXPERIMENTAL MethodS}

The samples studied have been collected about 10 km north of Málaga (Fig. 1). On the basis of their texture, mineral assemblages and IC data, these samples belong to the upper epizone (Ruiz Cruz \& Rodríguez Jiménez 2002). The mineral assemblages were investigated by means of X-ray diffraction (XRD), optical microscopy (OP), electron-microprobe analysis (EMPA), and transmission electron microscopy (TEMAEM).

X-ray patterns, obtained from hand-enriched concentrates of spots and from the spot-free areas of the spotted slates, were recorded using a Siemens D-5000 diffractometer with $\mathrm{Cu} K \alpha$ radiation and graphite monochromator, operated at $40 \mathrm{~mA}$ and $40 \mathrm{kV}$ with a $0.01^{\circ}$ step size and $1 \mathrm{~s}$ counting time. Random samples from slates and from concentrates of spots were used for determinations of the semiquantitative mineralogical composition and of the $b$ parameter of the mafic phyllosilicates. Oriented samples, obtained in the air-dried state (natural and $\mathrm{Mg}$-saturated samples), after ethylene glycol solvation and after heating at $550^{\circ} \mathrm{C}$, were used for phyllosilicate identification.

Polished and carbon-coated thin sections were imaged using back-scattered electrons and analyzed by electron microprobe (EMPA), using a Cameca SX-50 apparatus. ZAF corrections and data reductions were performed with the software package supplied by Cameca. The accelerating voltage was $20 \mathrm{kV}$, and the beam current, $20 \mathrm{nA}$. In order to minimize volatilization of light elements, the spot size was set to $5 \mu \mathrm{m}$. Under routine operating conditions, the accuracy is about $1.5 \%$ of the measured concentrations. We used the following standards: wollastonite for $\mathrm{Si}$ and $\mathrm{Ca}$, synthetic $\mathrm{Al}_{2} \mathrm{O}_{3}$ for $\mathrm{Al}$, orthoclase for $\mathrm{K}$, albite for $\mathrm{Na}$, synthetic $\mathrm{Fe}_{2} \mathrm{O}_{3}$ for $\mathrm{Fe}$, periclase for $\mathrm{Mg}$, and synthetic $\mathrm{MnTiO}_{3}$ for $\mathrm{Mn}$ and Ti.

Thin sections cut perpendicular to the main schistosity were used for the investigation by transmission and analytical electron microscopy (TEM-AEM). Grids were attached to selected areas and later separated from the glass backing. These areas were ion-thinned and carbon-coated and examined with a $200 \mathrm{kV}$ Philips CM20 transmission electron microscope, operating at 200 $\mathrm{kV}$, equipped with an EDAX solid-state EDX detector (ultrathin window). Samples were thinned with a Gatan dual ion-mill, using an accelerating voltage of $6 \mathrm{kV}$ during three stages: (a) incidence angle of $15^{\circ}$ and probe current of $1 \mathrm{nA}$, (b) incidence angle of $15^{\circ}$ and probe current of $0.6 \mathrm{nA}$, and (c) incidence angle of $12^{\circ}$ and probe current of $0.4 \mathrm{nA}$. The scanning TEM mode was used for quantitative analyses of particles using a $40 \AA$ 
diameter beam and variable scanning area, according to the size of the packets. Counting times of $200 \mathrm{~s}$ were used except for $\mathrm{Na}$ and $\mathrm{K}$, for which we used a 30-s counting time. Muscovite, albite, spessartine, olivine and titanite were used as standards to calculate K-factors by the thin-film method of Lorimer \& Cliff (1976). Although numerous analyses were carried out, only those obtained from areas well characterized by latticefringe images and electron-diffraction patterns were used in tables and figures. Normalization of muscovite and biotite formulae was based on charge balance relative to 11 atoms of oxygen. Normalization of berthierine and chlorite compositions followed the approach of Jiang et al. (1992) (charge balance relative to 14 atoms of oxygen and a total of $\leq 10$ tetrahedrally and octahedrally coordinated cations). The relative number of $\mathrm{Fe}^{2+}$ and $\mathrm{Fe}^{3+}$ ions was determined by charge balance.

\section{RESULTS}

\section{Optical microscopy}

Spotted slates show a variable proportion of spots. These attain about $18 \%$ by volume in samples showing the greatest development. Slates show a well-defined schistosity, and a common crenulation. Schistosity is marked by the presence of thin alternating bands that are quartz-, mica- or chlorite-rich. In spite of the small size of the phyllosilicate grains, chlorite-rich bands are easily distinguished by a slight brown pleochroism, which characterizes, in the Maláguide suite, the Fe-rich chlorite containing some ferric iron (Ruiz Cruz 1997). The more striking differences among the samples studied are textural, and concern the degree of spot development. The spots either overprint or preserve the pre-existing schistosity, and show differently zoned textures, to be described here.

Most of the spots are ovoid and are on the order of $0.5-2 \mathrm{~mm}$ across. Spots preferentially develop in chlorite- and mica-rich bands, and show a variable development of concentric zones (Fig. 2). Spots formed from chlorite- and oxide-rich bands are characterized by the presence of an outer yellow to reddish zone, which surrounds an inner lighter zone (Fig. 2A). The thickness of these zones is also dependent of the degree of spot development. Those spots formed in mica-rich bands are colorless, although they generally appear surrounded by a yellow outer rim of very variable development. These spots appear is some cases formed by aggregates of phyllosilicates and quartz (Figs. 2C, D) but, more commonly, their birefringence is notably lower than that of the enclosing slates (Fig. 2B). The greatest development of spots is found in mica- and chlorite-rich bands (also including quartz-rich bands), and the zonation is not homogeneous, the yellow outer rim being restricted to some zones of the spot, and the colorless area being better developed. The spots shown in Figure 2 were selected for the EMPA study, and a set of spots with simi- lar optical characteristics were used for the TEM-AEM study.

\section{$X$-ray diffraction}

The characteristic mineral assemblage of the slates, deduced from the XRD patterns, is quartz + albite + muscovite + chlorite, although minor mica-chlorite mixed-layers are present in some of the samples. Mineralogical characteristics of the samples selected have been summarized in Table 1. Differences among the samples studied concern the mica:chlorite ratio, and the presence or lack of chlorite-bearing mixed-layers.

X-ray-diffraction patterns of both the slates and the concentrates of spots do not show evident mineralogical distinctions, although a chlorite enrichment relative to mica and an increase in the intensity of the 7 - $\AA$ relative to the $14-\AA$ reflection may be observed in the patterns of the spots (Fig. 3). The most significant difference involves the position of the 060 reflection of the trioctahedral phases, which shifts from $1.550 \AA$ in slates to $1.561 \AA$ in spot-enriched concentrates (values corresponding to $b_{0}=9.30$ and $9.37 \AA$ ), a change that suggests an enrichment in Fe (Brown \& Brindley 1980). Chlorite from spot-free slates displays X-ray traces similar to those obtained in typical Maláguide metaclastites with a similar metamorphic grade. These features are intense odd reflections and weak even reflections, which are characteristic of Fe-rich specimens (Ruiz Cruz \& Moreno Real 1996). The random patterns show a distribution of $20 l(13 l)$ diffraction intensity characteristic of a II $b$ polytype, or the subfamily C (Weiss 1991). The muscovite reflections correspond to a $2 M_{1}$ polytype (Bailey 1980a).

\section{Electron-microprobe results}

The most significant chemical changes associated with spot formation, relative to the enclosing slates, have been evaluated with the electron-microprobe results. These do not permit the exact chemical characterization of the several phases because the small size of the grains, but provide useful information about the distribution of the major chemical components within several zones in

\begin{tabular}{|c|c|c|c|c|c|}
\hline Sample & $\begin{array}{l}\text { Schistority } \\
\text { in spats }\end{array}$ & $\begin{array}{l}\text { Assenblage } \\
\text { of minerals }\end{array}$ & $\mathrm{Ms}^{\prime} \mathrm{CH}^{*}$ & $\mathrm{IC}$ & $c$ \\
\hline $\mathrm{CH}-30$ & Overprinted. & $\mathrm{Otz}+\mathrm{Ab}+\mathrm{Ms}+\mathrm{Chl}$ & 1.6 & 0.28 & 0.22 \\
\hline $\mathrm{CH}-37$ & Prescrtwed & $Q_{2}+A b+M_{s}+C h t+M L$ & 4,1 & 0.24 & 0.26 \\
\hline $\mathrm{CH}_{-39}$ & Partially preserved & $Q t a+4 b+M s+C b$ & 1.1 & 0.23 & 0.26 \\
\hline
\end{tabular}

* This ratio has been directly estimated as the intensicy ratio of the $10-A$ reflection of mica and the $7 . A$ reflection of chlorite. IC. Illite erribellinity $\mathrm{CC}$ : Chlorite crystallinity (from Ruiz Cruz \& Rodriguez Jimáncs 2002). MI: Mica-chlorite

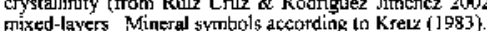


the spots. The results of the EMPA data obtained along the sections marked in Figure 2 have been plotted in Figures 4, 5 and 6. In these plots, the greatest Si contents mainly reflect the contribution of quartz, whereas the highest contents in $\mathrm{Fe}, \mathrm{K}$ and $\mathrm{Na}$ reflect, respectively, the contribution of chlorite-like phases, mica and albite. A slight increase in Ti content indicates, on the other hand, the presence of biotite.

In spots formed in chlorite-rich slates (Figs. 2A, 4), the zonal structure is clearly reflected in the distribution of the major elements. This plot reveals an enrichment in quartz in the inner zone, relative to the reddish outer rim. The distribution of both $\mathrm{Fe}$ and $\mathrm{Mg}$ also reflects the observed zonation. These elements show a strong positive correlation outside the spots, since they are mainly held in chlorite. This correlation is not observed in the reddish outer rim, where Fe content systematically increases, whereas Mg content show a lower, homogeneous concentration. In the innermost zone, again a positive correlation is observed, the content of both
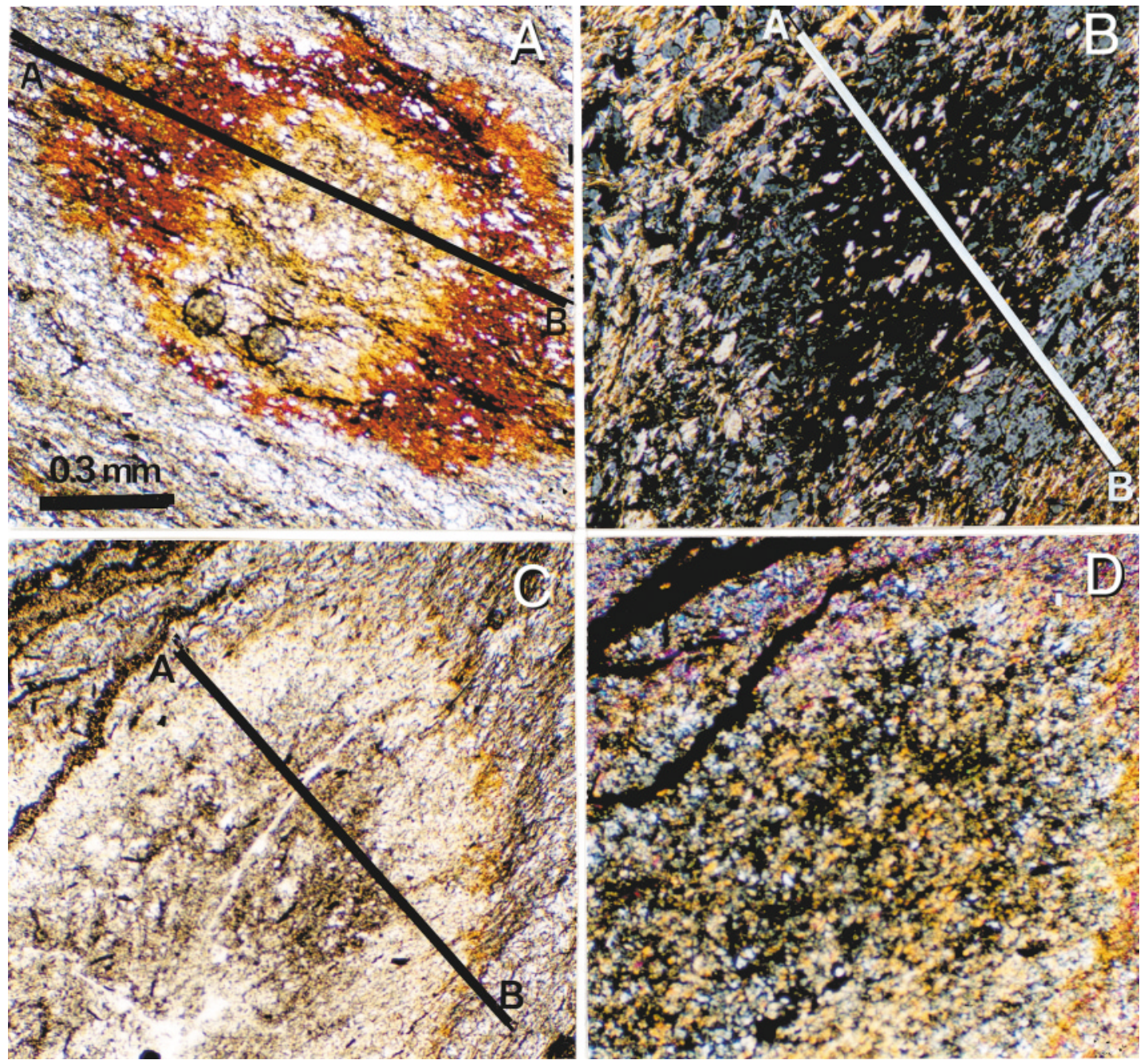

FIG. 2. Photomicrographs showing the most significant textural features of the spots. A. Zoned spot with an outer Fe-rich area (red) and a Si-enriched core (parallel nicols, sample $\mathrm{CH}-39$ ). B. Poorly defined light spot with a narrow and incomplete yellow rim. The zonation consists of an outer quartz-rich zone and an inner isotropic zone, both containing numerous lamellae of mica (crossed nicols, sample $\mathrm{CH}-30$ ). $\mathrm{C}$ and $\mathrm{D}$. Zoned spot with a narrow outer yellow rim and an inner micaceous core (parallel and crossed nicols, sample $\mathrm{CH}-30$ ). The lines mark the position of the profiles along of which the EMPA data shown in Figures 4, 5 and 6 were obtained. The scale is common for all the photomicrographs. 


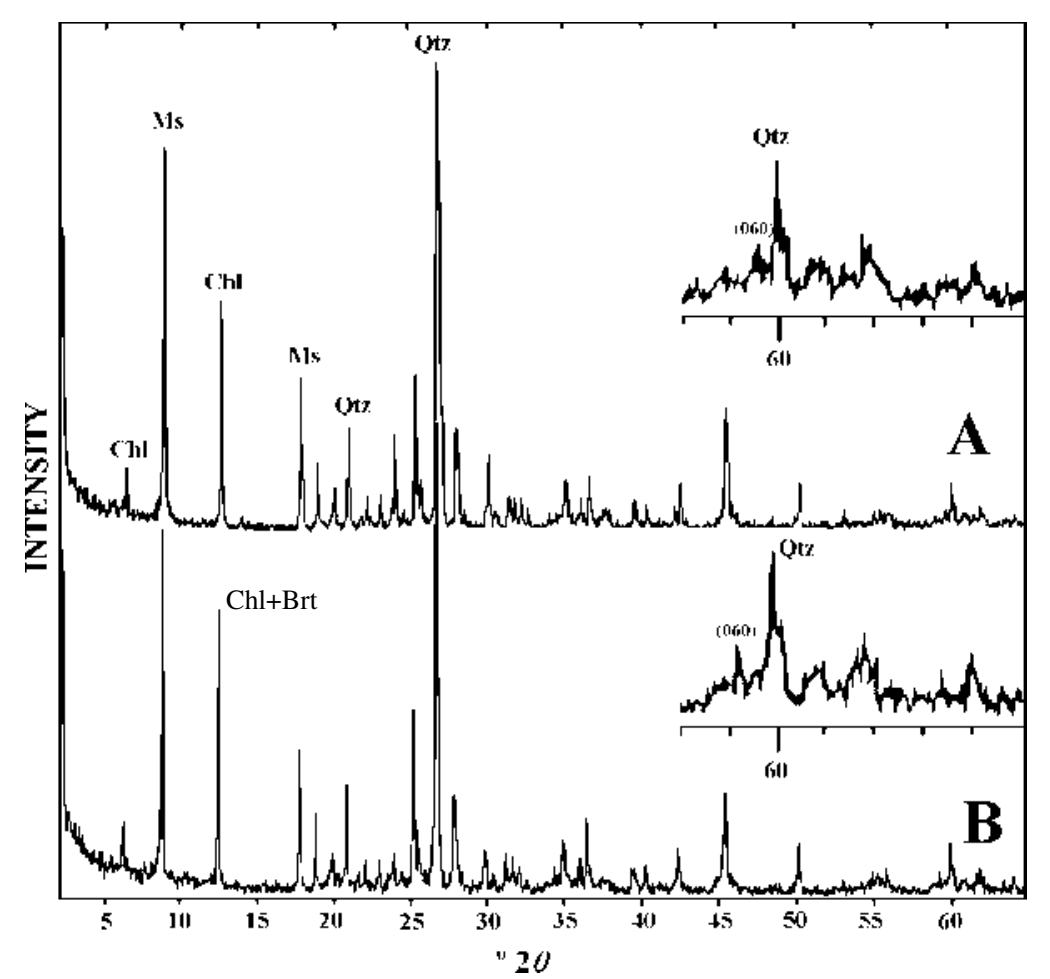

FIG. 3. X-ray-diffraction patterns (random samples) obtained from spot-free areas of slates (A) and from concentrates of spots (B). Qtz: quartz, Ms: muscovite, Chl: chlorite, Brt: berthierine.

$\mathrm{Fe}$ and $\mathrm{Mg}$ being more homogeneous than beyond the spots. Na and $\mathrm{K}$ contents show a symmetrical distribution almost parallel to that of Fe. In the slates, these elements show a negative correlation related to their different distribution either in mica $(\mathrm{K})$ or in albite $(\mathrm{Na})$. Within the spots, both $\mathrm{K}$ and Na contents decrease, and their positive correlation indicates that $\mathrm{Na}$ forms part of the mica phases.

The chemical variations observed in micaceous spots, such as those shown in Figures $2 \mathrm{C}$ and D, are mainly reflected by the relative variations of $\mathrm{Si}$ and $\mathrm{Al}$ as well as in the (Fe $+\mathrm{Mg}$ ) distribution (Fig. 5). In this spot, the narrow outer rim shows the highest $(\mathrm{Fe}+\mathrm{Mg})$ content, whereas the concentration of these elements clearly decreases in the core of the spots. On the other hand, the high $\mathrm{K}$ content reflects the mica-rich nature of the spot. Nevertheless, some areas of the spot show a clear increase in $\mathrm{Al}$, which leads to $\mathrm{Si} / \mathrm{Al}$ values near 1.

A more complete chemical transformation is observed in some other spots, such as that shown in Figure $2 \mathrm{~B}$, although the presence of quartz-rich bands prevents the development of a symmetrical zonation. In this case (Fig. 6), a well-developed isotropic inner zone is characterized by the lack of quartz, resulting in ho- mogeneous $\mathrm{Si}$ and $\mathrm{Al}$ contents. This area is also depleted in both $\mathrm{Fe}$ and $\mathrm{Mg}$. Variations in $\mathrm{K}$ and $\mathrm{Na}$ in this zone reflect the presence of small micaceous grains that are homogeneously distributed. The transition from the isotropic zone to the outer rim occurs through a quartzrich zone.

\section{Transmission-analytical electron microscopy of spot-free areas of spotted slates}

TEM images of spot-free areas of the spotted slates show that crystals of muscovite and chlorite are oriented parallel to the planes of schistosity, and have undergone variable degrees of deformation. Muscovite and chlorite grains seem to form parallel packets with a thickness of the order of 0.2 to $0.5 \mu \mathrm{m}$. Muscovite shows lattice-fringe images displaying periodicities of both 10 and $20 \AA$, and the selected-area diffraction (SAED) patterns reveal an ordered two-layer polytype (Fig. 7A). The high-resolution images of the non-deformed chlorite crystals show a high regularity and rare structural defects. The SAED patterns obtained in different packets of chlorite correspond to ordered one-layer and twolayer polytypes (Fig. 7B). 

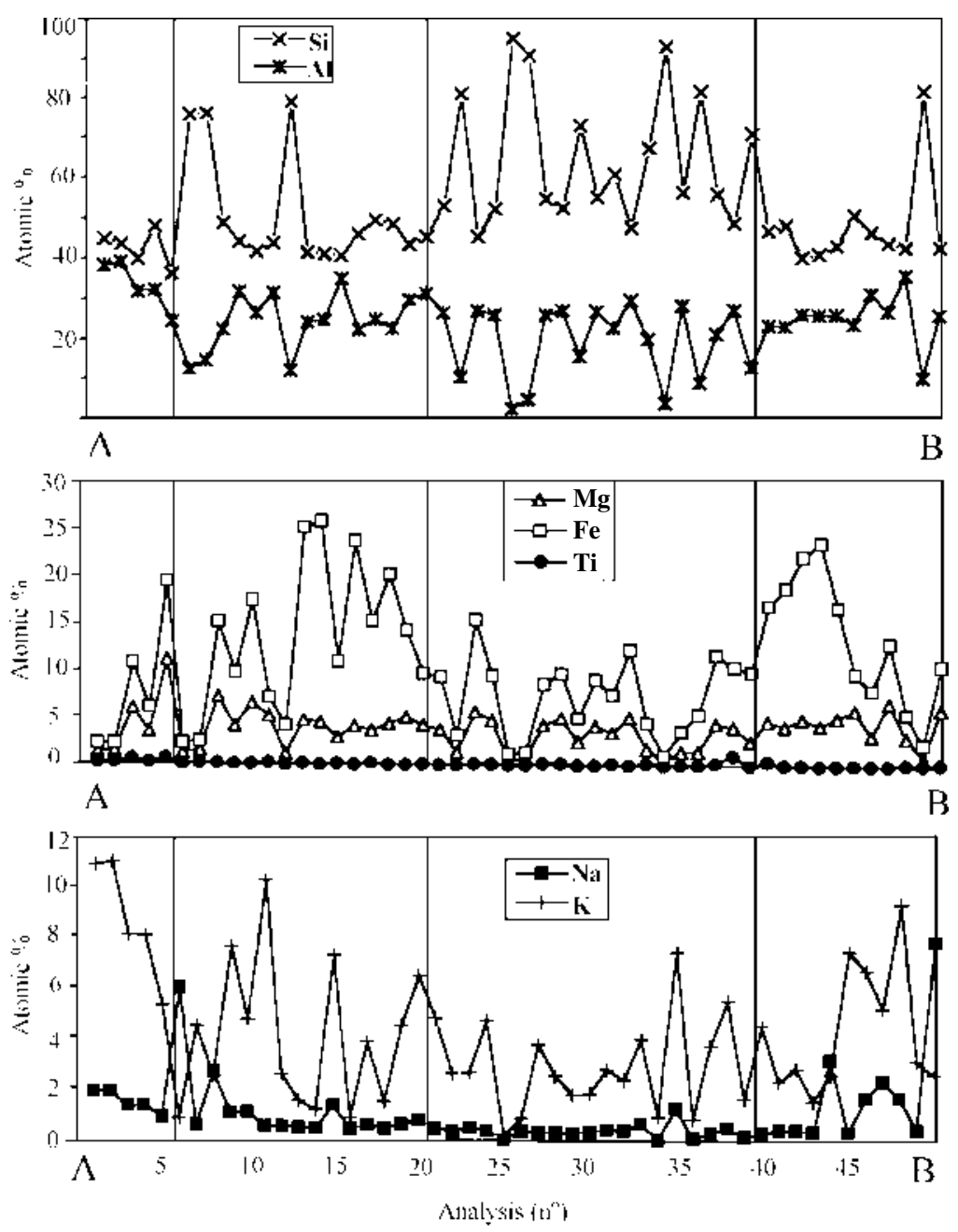

FIG. 4. Chemical variations along the spot shown in Figure 2A. Vertical lines mark the limits between adjacent zones.

AEM data on muscovite (Table 2) indicate that the $\mathrm{K}$ content is commonly lower than 1 apfu (atom per formula unit, calculated for $11 \mathrm{O}$ ). Nevertheless, if the analyses are done with a larger window, the $\mathrm{K}$ content notably increases, indicating that $\mathrm{K}$ is partially lost during the analyses. The determination of the exact $\mathrm{Si}$ content is, as a result, imprecise, but it ranges between 3.10 and $3.25 a p f u$. The $(\mathrm{Fe}+\mathrm{Mg})$ content also is variable, reaching up $0.50 a p f u$. AEM data on chlorite show a high ${ }^{\mathrm{IV}} \mathrm{Al}$ content (from 1.28 to $1.50 \mathrm{apfu}$ ) and a high Fe content. The structural formulae show a slightly lower $\mathrm{Si}$ content than most of the chlorite in spot-free slates with similar stratigraphic position. Such chlorite may be classified as chamosite, following the recommenda- tions of the AIPEA Nomenclature Committee (Bailey 1980b).

\section{Transmission-analytical electron microscopy of spots}

Our TEM observations and, especially, the AEM data obtained in differently textured spots, reveal that they contain two characteristic mineral associations which, although present, are developed to a very variable degree, in most of the spots studied. The assemblage muscovite + berthierine (with occasional chlorite) is the most abundant in the yellow to reddish spots, such as that shown in Figure 2A, where it appears in both the outer zone and the innermost part of the spots, in con- 

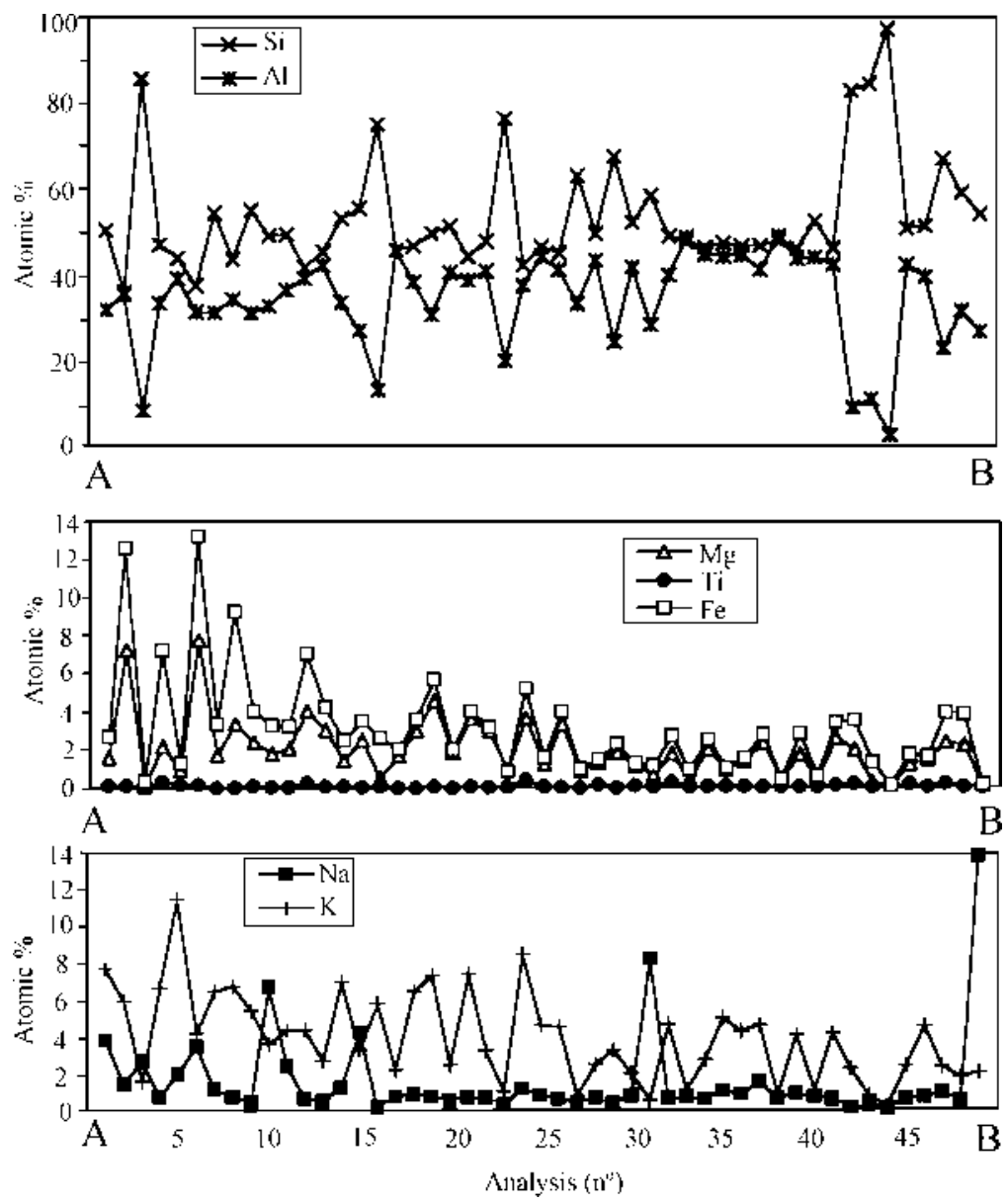

FIG. 5. Chemical variations along the spot shown in Figures 2C and 2D.

tact with amorphous phases. The second assemblage contains muscovite + chlorite + biotite, and preferentially develops in micaceous spots, such as that shown in Figures 2C and D. Both associations commonly coexist within a single spot, berthierine being dominant in the yellow, Fe-rich zone.

\section{The muscovite + berthierine \pm chlorite assemblage in the spots}

In the outer zone of the spots, muscovite and berthierine form either crystals containing a single phase or a fine intergrowth of the two phases. The presence of chlorite packets is also common in these areas. The two types of packets show variable size and generally display important signs of deformation (berthierine packets) and signs of damage (muscovite and muscoviteberthierine intergrowths). In Figure 8A, the berthierine packet appears intensely deformed, whereas the com- posite muscovite-berthierine intergrowth, with a different orientation, appears to be almost undeformed. The high-resolution images of the discrete packets of berthierine (Fig. 8B) commonly show large areas with regular 7 - $\AA$ periodicity, in which 14 - $\AA$ fringes appear regularly spaced. The SAED patterns only show reflections with a $7-\AA$ spacing, which confirms that these packets have a serpentine-like structure. Intergrowths of 14- $\AA$ and 7- $\AA$ layers have been previously described (e.g., Amouric et al. 1988, Slack et al. 1992, AbadOrtega \& Nieto 1995), the 14- $\AA$ layers being interpreted either as chlorite layers or as two layers of $7-\AA$ berthierine. In this case, the observation of numerous transitions from 7 - $\AA$ to 14 - $\AA$ periodicities along the layers, as well as the presence of bands with a strain contrast oblique to (001), indicate (Jiang et al. 1992) that the $14-\AA$ fringes correspond to layers of true chlorite rather than to two layers of berthierine, and suggest that berthierine formed from chlorite. 

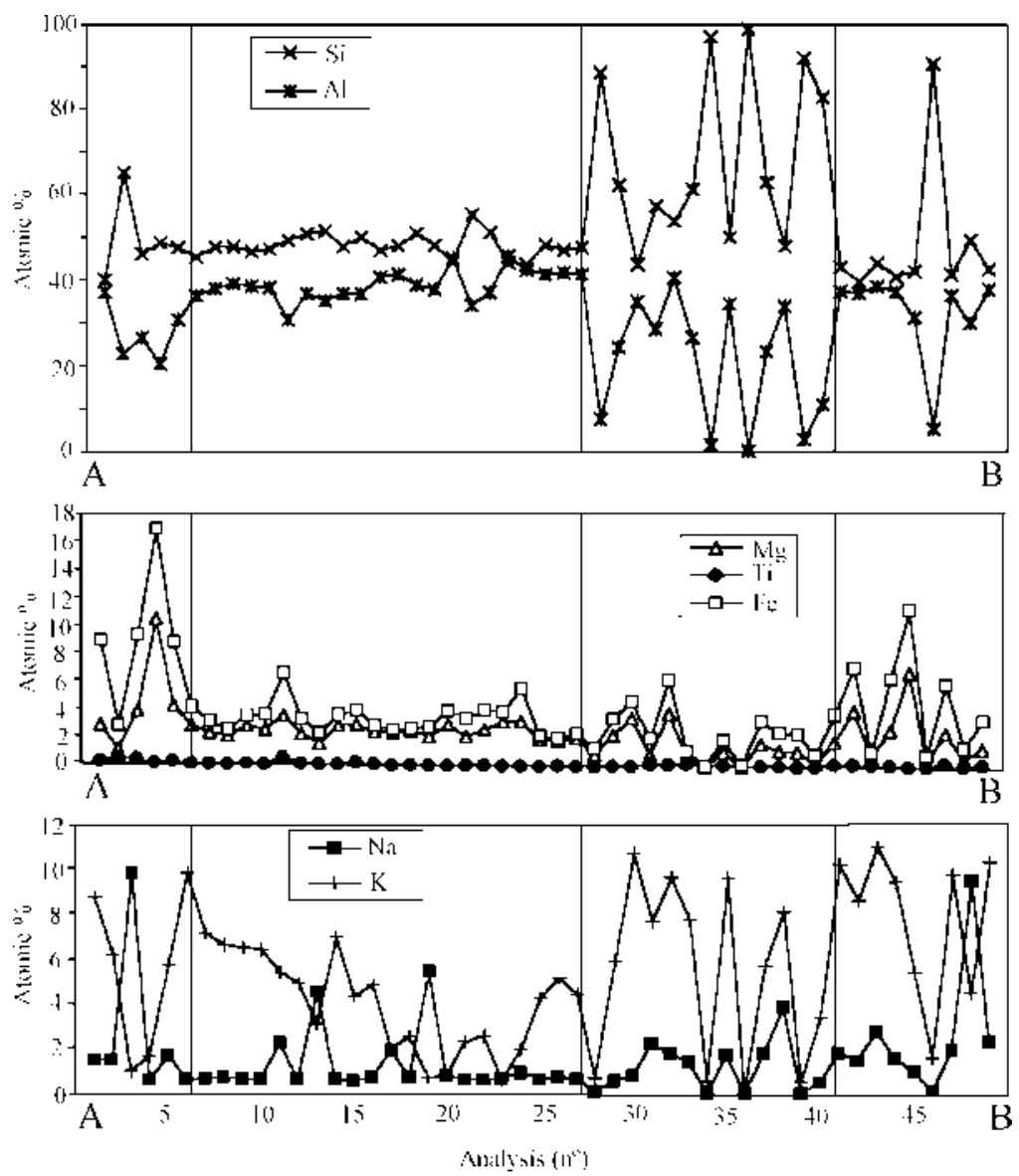

FIG. 6. Chemical variations along the spot shown in Figure 2B. Vertical lines mark the limits between adjacent zones.

The composition of the packets showing a 7-A periodicity correspond to a $\mathrm{Fe}-\mathrm{Al}-\mathrm{Mg}$ phyllosilicate, similar to Fe-rich oxidized chlorite (Table 3). The structural formulae, calculated on the basis of 14 atoms of oxygen, indicate that ${ }^{\mathrm{IV}} \mathrm{Al}$ is on the order of $1.8 a p f u$. In the octahedral positions, $\mathrm{Al}$ content is generally lower, the charge deficit being compensated by the presence of $\mathrm{Fe}^{3+}$. In these cases, structural formulae have been calculated on the basis of 14 atoms of oxygen and with the assumption that there are six octahedral sites. Some of the formulae calculated are within the compositional field of berthierine, according to the data of Brindley (1982), although most of these show total Al content clearly lower than that characteristic of berthierine. In fact, the formulae obtained indicate some degree of solid solution between berthierine and another 7 - $\AA$ phase, presumably the $\mathrm{Fe}$ analogue of amesite (Bailey 1988). Since such intermediate phases appear in the same microdomains as the berthierine, and have no specific name, we will also use the name berthierine.

In these areas, muscovite crystals generally contain discrete packets of berthierine on the order of 50-100 thick, the transition $7 \AA-10 \AA$ being common along the layers. Figure 9 shows a complex intergrowth of muscovite, berthierine and mixed-layer muscoviteberthierine, with mineral boundaries preferentially parallel or subparallel to (001). This figure also shows evidence of termination of layers, with associated strain contrast, related to the change in layer periodicity. These structural defects seem concentrated within the packets of berthierine, where 1:1 regular interstratifications are locally observed. On the contrary, the packets showing 10 - $\AA$ periodicity display sparse structural defects. These types of textural relationships between muscovite and berthierine suggest that both mixed-layer phases and berthierine formed from a previous phase with a $10-\AA$ 
TABLF 2, RFPRESENTATIVE RESULIS OF AEM ANALYSES IV THE SPOTTED SLATES, MALAGLIDE COMPLEX, SPAIN

\begin{tabular}{|c|c|c|c|c|c|c|}
\hline \multirow[b]{2}{*}{ Element } & \multicolumn{3}{|c|}{ Muscorite } & \multicolumn{3}{|c|}{ Chlorite } \\
\hline & $\mathrm{CH}-30$ & $\mathrm{CH}-3.7$ & $\mathrm{CH}-39$ & $\mathrm{CH}-30$ & $\mathrm{CH}-3 \mathrm{~T}$ & $\mathrm{CH}-39$ \\
\hline $\begin{array}{l}\text { Si wt.\% } \\
\text { Al } \\
\mathrm{Fe} \\
\mathrm{Hg} \\
\mathrm{Wn} \\
\mathrm{Ti}_{\mathrm{i}} \\
\mathrm{K} \\
\mathrm{Ma}\end{array}$ & $\begin{array}{r}470] \\
3759 \\
1.15 \\
177 \\
-- \\
013 \\
11.18 \\
1.17\end{array}$ & $\begin{array}{r}45.09 \\
3843 \\
2.22 \\
1.26 \\
010 \\
018 \\
10.84 \\
1.88\end{array}$ & $\begin{array}{l}45.87 \\
3666 \\
4.13 \\
2.83 \\
- \\
- \\
9.93 \\
0.58\end{array}$ & $\begin{array}{l}27.24 \\
26.81 \\
29.06 \\
16.29 \\
0.61 \\
- \\
= \\
=\end{array}$ & $\begin{array}{l}27.28 \\
28.32 \\
32.02 \\
12.18 \\
0.20 \\
0.08 \\
-0.02\end{array}$ & $\begin{array}{l}2601 \\
2954 \\
2 T 01 \\
17.14 \\
0.01 \\
0.02 \\
-- \\
--\end{array}$ \\
\hline \multicolumn{7}{|c|}{ Structural formulae } \\
\hline 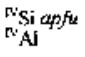 & $\begin{array}{l}3.23 \\
0.77\end{array}$ & $\begin{array}{l}3.13 \\
0.87\end{array}$ & $\begin{array}{l}3.18 \\
0.82\end{array}$ & $\begin{array}{l}2.72 \\
1.2 \mathrm{~B}\end{array}$ & $\begin{array}{l}2.71 \\
1.29\end{array}$ & $\begin{array}{l}2.58 \\
1.42\end{array}$ \\
\hline 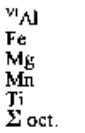 & $\begin{array}{l}1.82 \\
0.08 \\
0.12 \\
-- \\
2.02\end{array}$ & $\begin{array}{l}1.80 \\
0.15 \\
0.09 \\
- \\
001 \\
2.05\end{array}$ & $\begin{array}{l}1.72 \\
0.29 \\
0.20 \\
-- \\
-2.21\end{array}$ & $\begin{array}{c}139 \\
291 \\
162 \\
006 \\
-59 \mathrm{~B}\end{array}$ & $\begin{array}{c}1.52 \\
318 \\
1.21 \\
0.02 \\
- \\
5.93\end{array}$ & $\begin{array}{l}1.54 \\
2.68 \\
1.70 \\
-- \\
-5.92\end{array}$ \\
\hline $\begin{array}{l}\mathrm{K} \\
\mathrm{N} \mathbf{I}\end{array}$ & $\begin{array}{l}0.77 \\
0.08\end{array}$ & $\begin{array}{l}0.75 \\
0.13\end{array}$ & 0.69 & $\bar{z}$ & $\begin{array}{l}- \\
--\end{array}$ & $\begin{array}{l}-- \\
--\end{array}$ \\
\hline 0 & I] & ] ] & ] & 14 & 14 & 14 \\
\hline
\end{tabular}

Sormalization of muscovite formulae was basto on charge balince relative to I1 atoms at onrgen. Nomalization of ctuorite compositions followed the approach of Jiang er al (1962): charge balance relative to 14 atoms of oxygen and a total of $<10$ cetrahedrally and octahedratly coordinated cutioss. The relative number of $\mathrm{Fe}^{-}$and $\mathrm{Fe}^{3}$ ions wes determited by charge balanes apfi: atomis per formula unit. periodicity, which has been, to a great extent, preserved. The corresponding diffraction pattern shows the basal spots of both phases together with streaking corresponding to the interstratified phase. In these areas, berthierine compositions show a lower Fe content, probably reflecting the influence of the precursor phase.

The assemblage muscovite + berthierine also appears in contact with the optically isotropic areas. Figure 10 shows a composite stack of muscovite and berthierine in contact with "amorphous" phases. Lens-shaped pores are abundant in the berthierine packet as well as associated with the muscovite-berthierine boundaries, either oblique or parallel to (001). The "amorphous" phases appear at the TEM scale as short lamellae, commonly bent, and leading to rounded aggregates. The SAED patterns obtained of the "amorphous" areas (inset in Fig. 10) show a single diffraction-maximum at about $3.4 \AA$, similar to that observed in dehydrated kaolinite. The SAED patterns of muscovite and berthierine show, in these areas, streaking perpendicular to $c^{*}$, which reflects the bending of the packets, as well as some streaking parallel to $c^{*}$, indicating stacking disorder in both types of phases.

The AEM data of the muscovite packets (Table 3) reveal, in these areas, a $\mathrm{K}$ content clearly lower than 1 ,

TABLE 3. REPRESENT ATIVE RESULTS OF AEM AFAL YSES OF THE ASSEMBLAGE MUSCOVTE - BERTHERTNE - (AMORPHOUS PHASES), MALAGLIDE COMPLEX, SPAIN

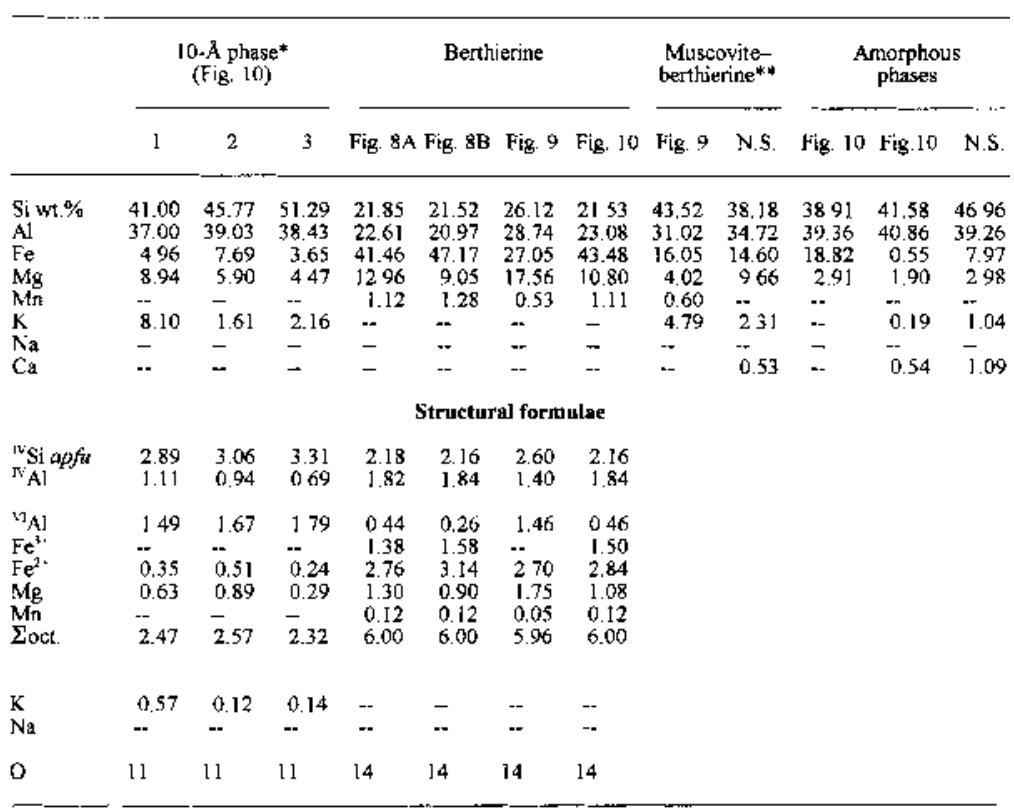

* The 10.A phase shows SAED patters charactefistic of mical but il is clearly depleted in K.

** Analyses of both muscovile-bertherine mixed-layers and fine intergrowths. N.S : Not shown in the figures. The normalization of berthierine compositions followed the approucth of Jiang et al. (1592): charge balance relative to 14 atoms of oxygen and a total of $\leq 10$ tetrahedrally and octahedrally condingated cations. The fclative nuthber of $\mathrm{Fe}^{2}$ and $\mathrm{Fe}^{\mathrm{l}}$ ions was deternitice by charge balatice. 
if the structural formulae are calculated on the basis of 11 atoms of oxygen, and a high $(\mathrm{Fe}+\mathrm{Mg})$ content, which probably reflects contamination by berthierine. The AEM data collected on the isotropic areas reveal that they contain $\mathrm{Si}$ and $\mathrm{Al}$, in a proportion similar to kaolinite, with a very variable content of $\mathrm{Fe}$ and $\mathrm{Mg}$ (Table 3).

\section{The muscovite - chlorite - biotite} assemblage in the spots

The second type of mineral assemblage is characterized by the presence of large stacks of the phyllosilicates muscovite, chlorite and biotite. In these areas, chlorite shows variable structural and chemical features. Disordered to very ordered polytypes appear either as alternating packets or within a single packet (Fig. 11A). Disordered chlorite is easily identified by the presence of alternating groups of layers with different contrast, probably reflecting semirandom stacking, which leads to rows of $0 \mathrm{kl}$ reflections forming almost continuous lines. The SAED patterns of the ordered chlorite are similar to those obtained in spot-free areas and correspond to the ordered one-layer polytype. The AEM data for both types of chlorite (Table 4) reveal that disorder is accompanied by slight changes in the $\mathrm{Si} / \mathrm{Al}$ value, which leads to high ${ }^{\mathrm{IV}} \mathrm{Al}$ content in the disordered packets. Since most of the calculated structural formulae
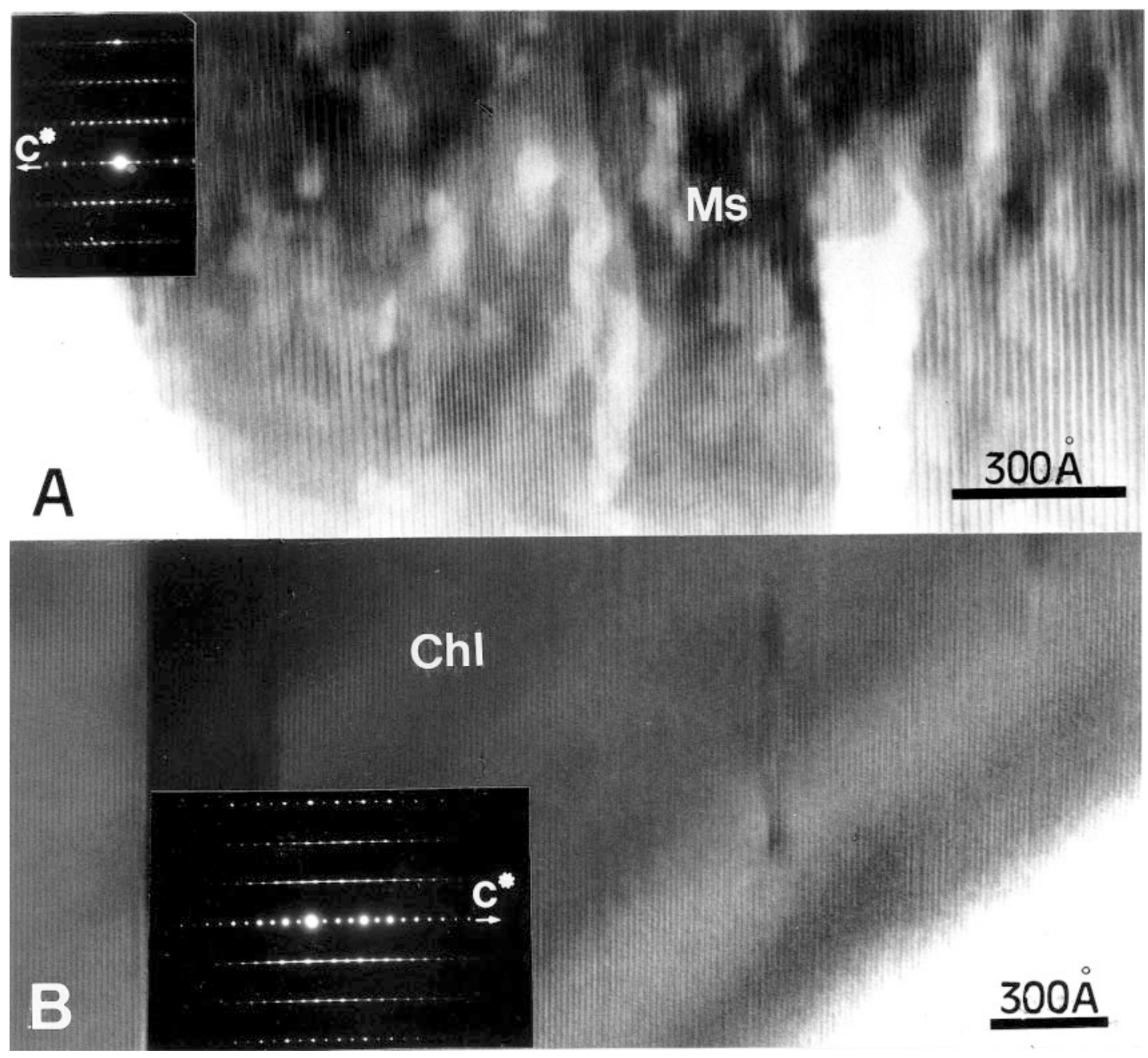

FIG. 7. TEM images of muscovite (A) and chlorite (B) in spot-free areas of the spotted slates. The SAED pattern of muscovite (inset in A) indicates a two-layer polytype. The SAED pattern of chlorite (inset in B) corresponds to a one-layer polytype. 

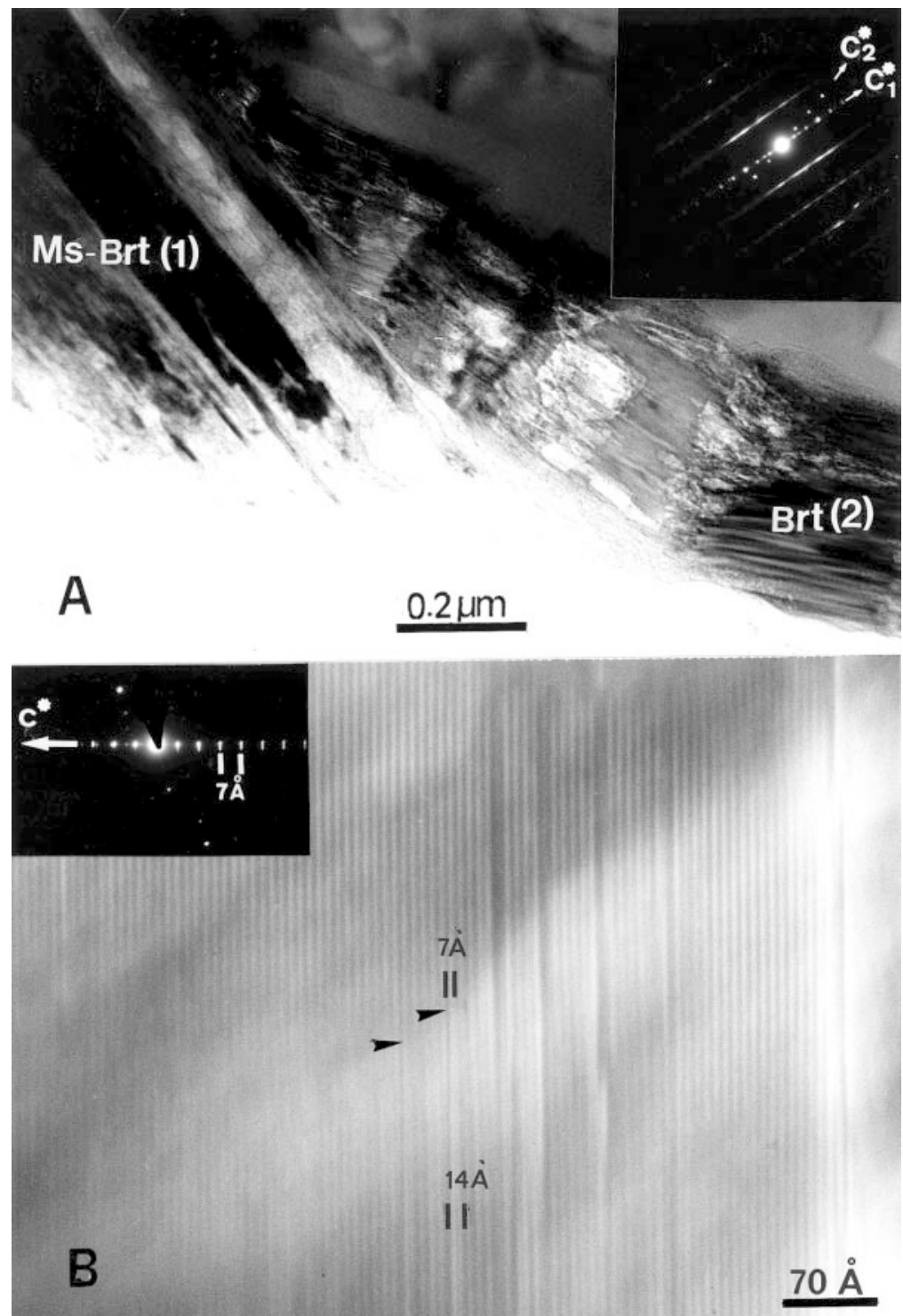

FIG. 8. A. Low-magnification TEM image of berthierine (Brt) and muscovite-berthierine (Ms-Brt) packets. The berthierine packet appears intensely deformed, whereas the muscovite-berthierine packet do not show signs of deformation. The SAED pattern (inset) shows the basal reflections of both berthierine and muscovite. Numbers on the packets correspond to numbers on the $00 l$ reflection rows of the SAED pattern. B. Highresolution image of a berthierine packet showing 7-Å periodicity. Some fringes with $14-\AA$ periodicity appear interstratified. Arrows mark layer transition (from $7 \AA$ to $14 \AA$ ).

show ${ }^{\mathrm{IV}} \mathrm{Al}>{ }^{\mathrm{VI}} \mathrm{Al}$, the stipulation that octahedral occupancies be equal to 6 also requires, as in berthierine compositions, that some Fe be ferric iron. Thus, the disordered polytypes of chlorite show tetrahedral occu- pancy and Fe content intermediate between the ordered chlorite and berthierine. AEM data on muscovite reveal a high content of $\mathrm{Na}$ (about 25\%). 
In low-magnification images, packets of biotite appear to be defect-free (Fig. 11B), and generally show well-defined changes in contrast, suggesting (001)twinned lamellae (Deer et al. 1976). Lattice-fringe images show that packets of biotite are commonly interstratified with 14- $\AA$-type layers (Fig. 12). These seem regularly spaced within the biotite packets, either showing continuity or changing, along the layers, to 10$\AA$ layers, the transition being responsible for the bending of the layers. The interstratified $14-\AA$ fringes may be interpreted as being due to two layers of berthierine or to one layer of chlorite. The fact that all the observed interstratified packets contain a number of layers that is an even multiple of 7 indicates, however, that these correspond to true chlorite.

In spite of a variable concentration of structural defects, the AEM data for biotite (Table 4) reveal a uniform composition, with a Si content near $2.5 \mathrm{apfu}$, and an $\mathrm{Al}$ content on the order of $1.8 \mathrm{apfu}$. Biotite also contain $\mathrm{Na}$ in proportions similar to those of muscovite. The low but constant Ti content (from 0.08 to $1.2 \mathrm{apfu}$ ) also characterizes biotite.

\section{DISCUSSION}

\section{The spots: prograde or retrograde formation?}

On the basis of the spatial and textural relations (Kerrick 1991), the formation of spots could be related to a local contact metamorphism. A first question concerns the origin of the mineral assemblages described. Did they form during a prograde process or during the retrograde alteration of precursor phases? Most of the micaceous spots identified in the external zones of contact aureoles are considered to have formed from pre-existing cordierite (Pattison \& Tracy 1991). Nevertheless, in the Maláguide Complex, spotted slates containing cordierite or andalusite have not been identified. Moreover, in the spotted slates, both the texture and the mineralogy of the spots suggest a primary origin for

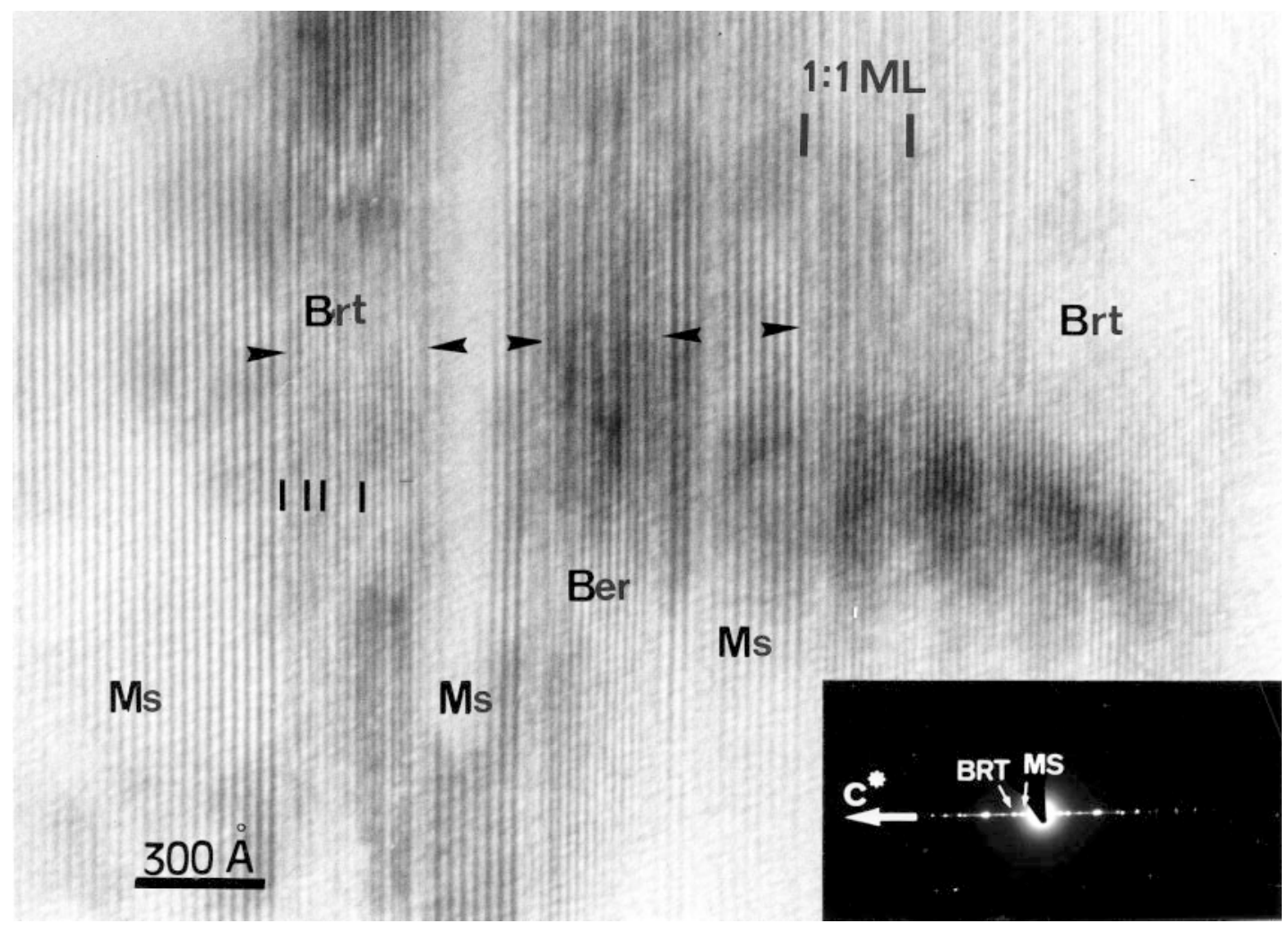

FIG. 9. High-resolution image of a composite muscovite-berthierine packet. The berthierine areas show both random and regular interstratifications with muscovite layers. The SAED pattern (inset) shows the basal reflections of both muscovite and berthierine. Bands of strain contrast almost perpendicular to (001) appear in the transition zone between mixed-layer packets and berthierine. Ms: muscovite, Brt: berthierine, ML: mixed-layer muscovite-berthierine. 

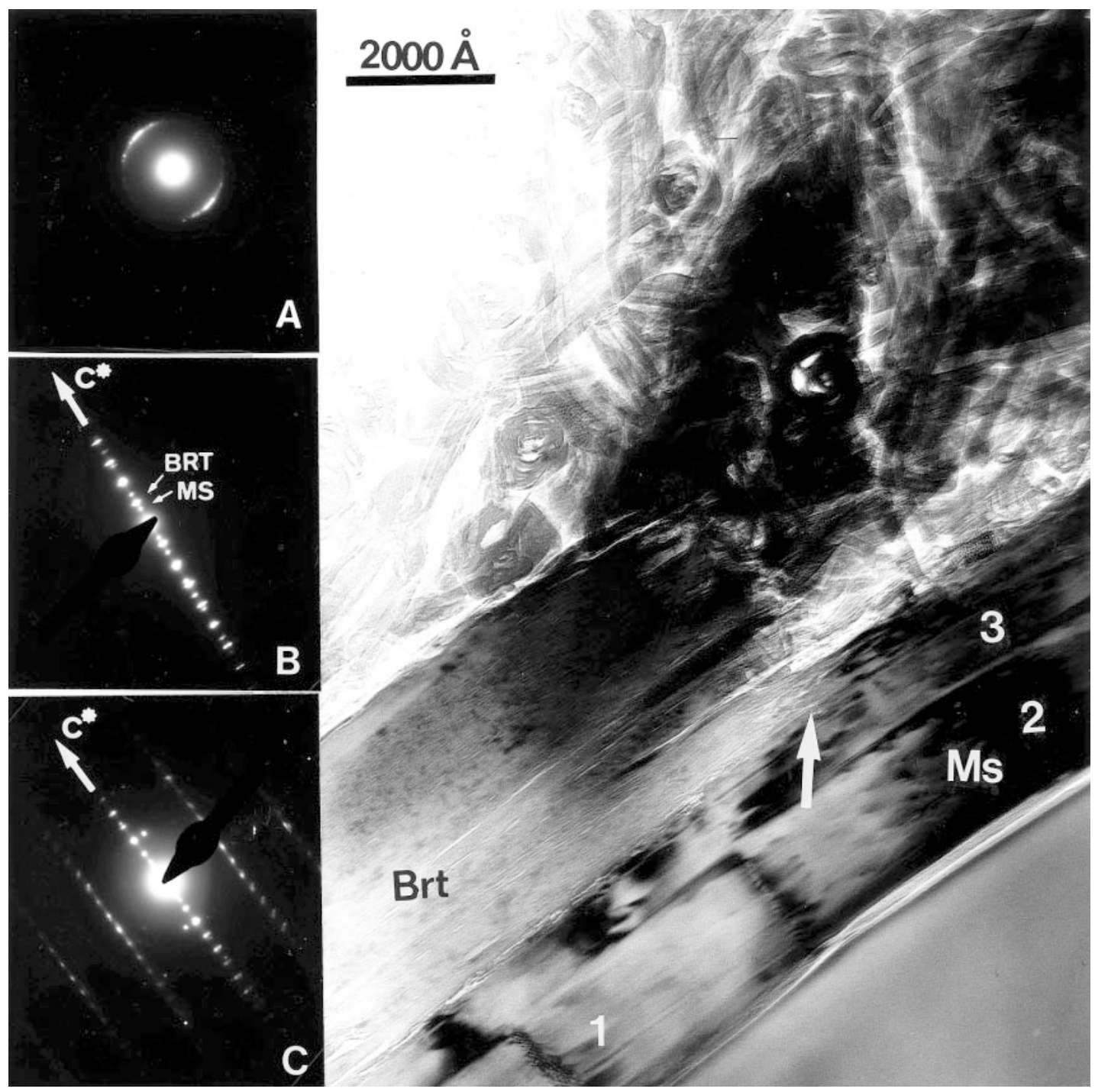

FIG. 10. Low-magnification TEM image showing the boundary between the phyllosilicates and the "amorphous" phases. Arrow marks the boundary between muscovite and berthierine, oblique to (001). The "amorphous" phases seem to consist of small lamellae, commonly curved. The SAED pattern of the "amorphous" phases (A) shows a maximum of the scattering band at about $3.40 \AA$. SAED B and C, which were respectively obtained in the berthierine and muscovite packets, show either intense reflections of berthierine and weak reflections of muscovite, or intense muscovite reflections and weak berthierine ones. Ms: muscovite, Brt: berthierine. Numbers indicate the areas in which the analytical results shown in Table 3 were obtained.

them. A clear continuity in the orientation of the phyllosilicates is observed from slates to poorly evolved spots, indicating that the phyllosilicates in the spots represent a transformation of those in the slate. On the contrary, the transformation of large crystals of precursor phases mainly lead to phyllosilicate veinlets and unoriented aggregates, and even where phyllosilicates show a clear orientation, they follow favorable struc- tural directions of the parent phases, as observed in the transformation of feldspars to kaolinite and white mica, and in chlorite formed from andalusite (Ahn \& Buseck 1988). On the other hand, the observed associations of minerals are difficult to explain by the breakdown of andalusite or cordierite. Retrograde alteration of andalusite would mainly lead to Al-rich phases such as kaolinite, muscovite, margarite and donbassite (Kerrick 


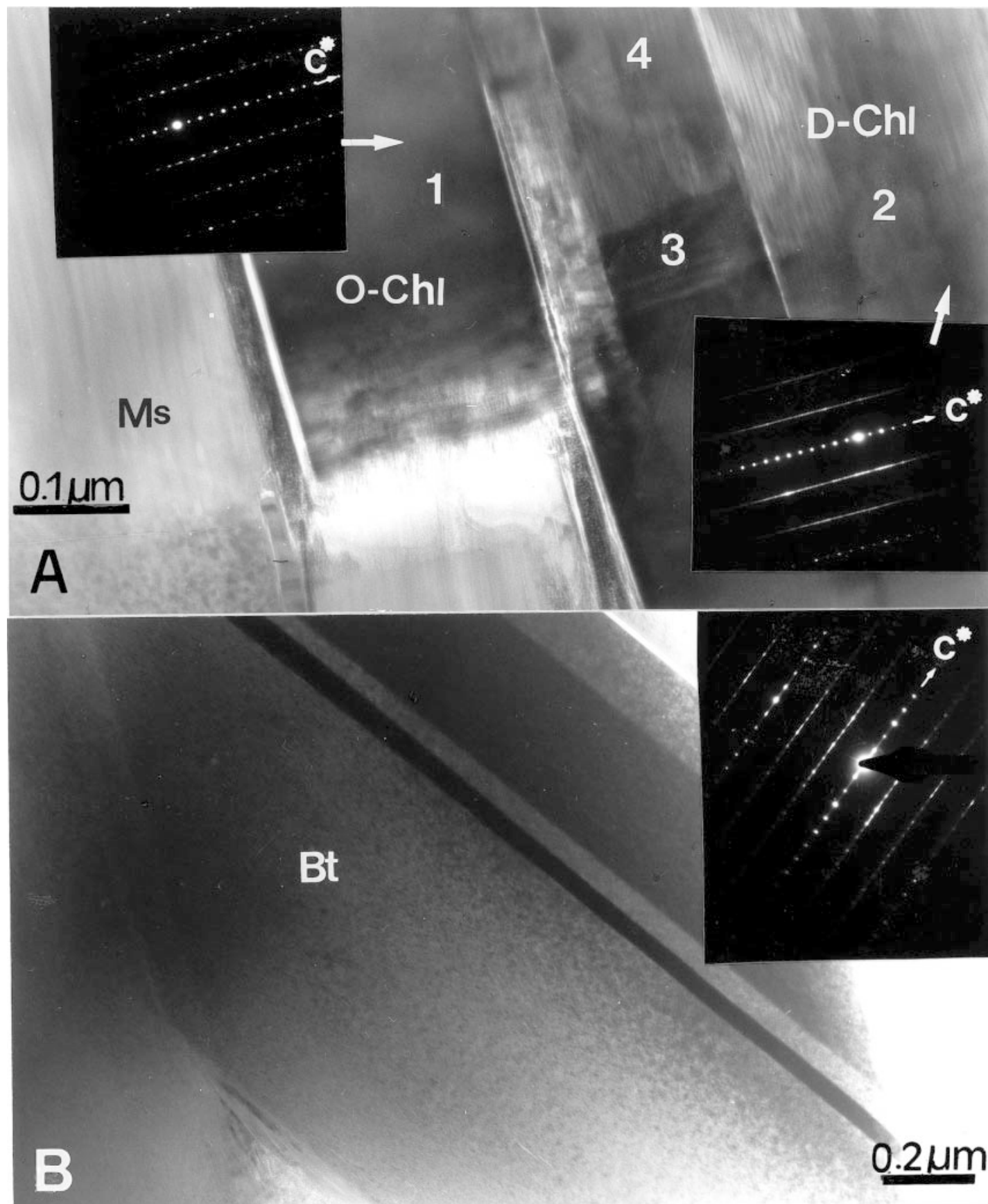

FIG. 11. A. Low-magnification TEM image of muscovite-chlorite packets. The SAED patterns (inset) correspond to adjacent packets of ordered $(\mathrm{O}-\mathrm{Chl})$ and disordered (D-Chl) chlorite. Numbers indicate the areas in which the analyses of chlorite shown in Table 4 were obtained. B. Low-magnification image of biotite, showing (001)-twinned lamellae. The SAED pattern (inset) corresponds to a two-layer polytype. 
1990), whereas the alteration of cordierite only would lead to $\mathrm{Fe}-\mathrm{Mg}$ phyllosilicates, as observed by AbadOrtega \& Nieto (1995). Thus, we interpret the spots as formed by the direct transformation of slates during the prograde stage of thermal metamorphism, probably below the andalusite zone.

\section{Phyllosilicate transformations during spot formation}

Both the AEM data and the structural information deduced from the SAED patterns have permitted us to follow the most significant modifications that affected the original phyllosilicates in the slate during spot formation. As pointed out, two different associations have been identified, either in different spots or in different areas of a single spot, suggesting that the reactions followed two different paths, which, respectively, led to the formation of berthierine or biotite.

Some berthierine packets contain $14-\AA$ chlorite layers and show abundant deformation-induced features (Fig. 8). Both facts suggest that berthierine formed from chlorite through a topotactic reaction, which would fa-

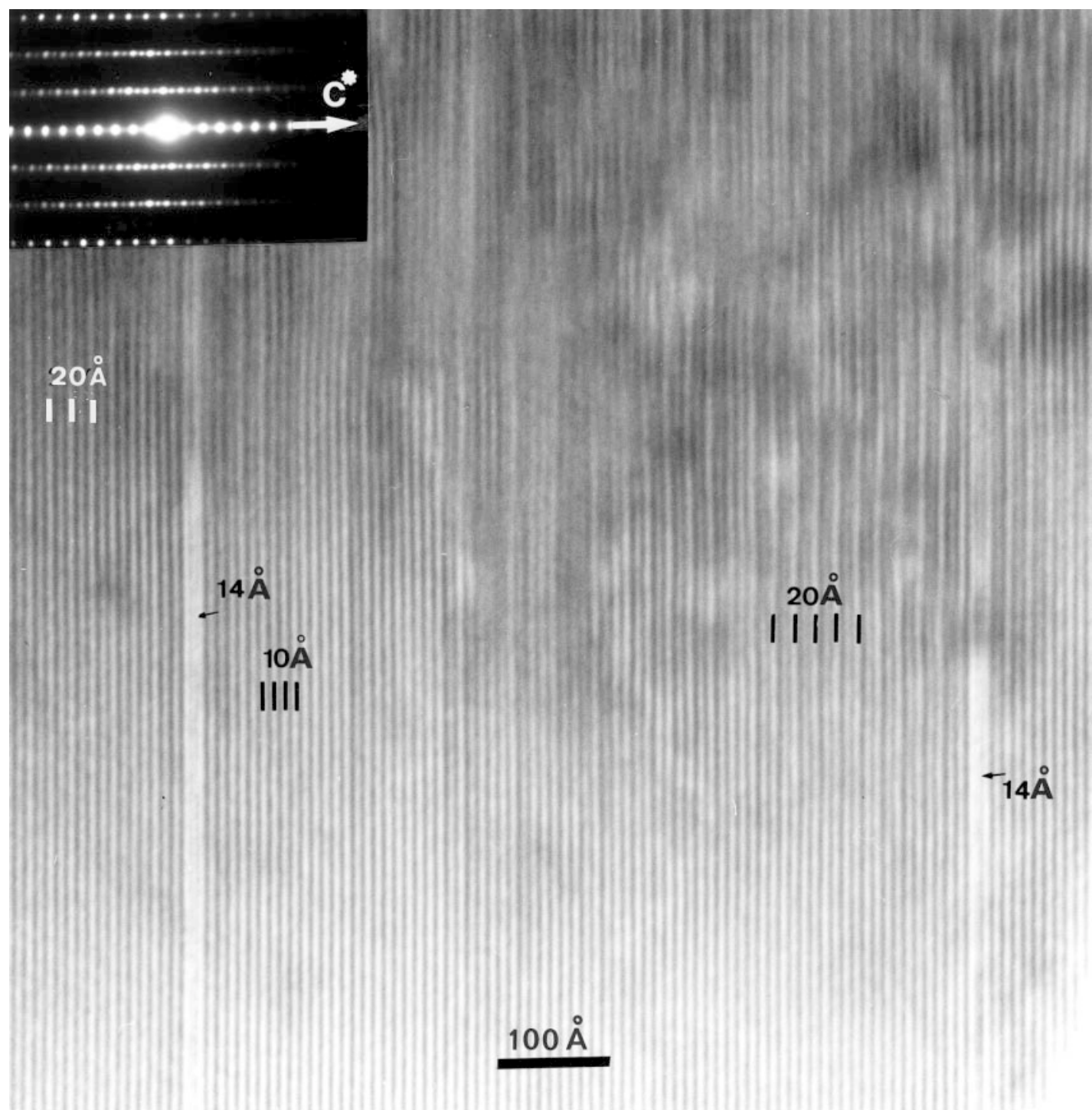

FIG. 12. Lattice-fringe image of biotite, showing interstratified layers with 14-Å periodicity. Biotite fringes show either $10-\AA ̊$ or 20 -Å periodicities. The SAED pattern (inset) corresponds to a well-ordered two-layer polytype. 

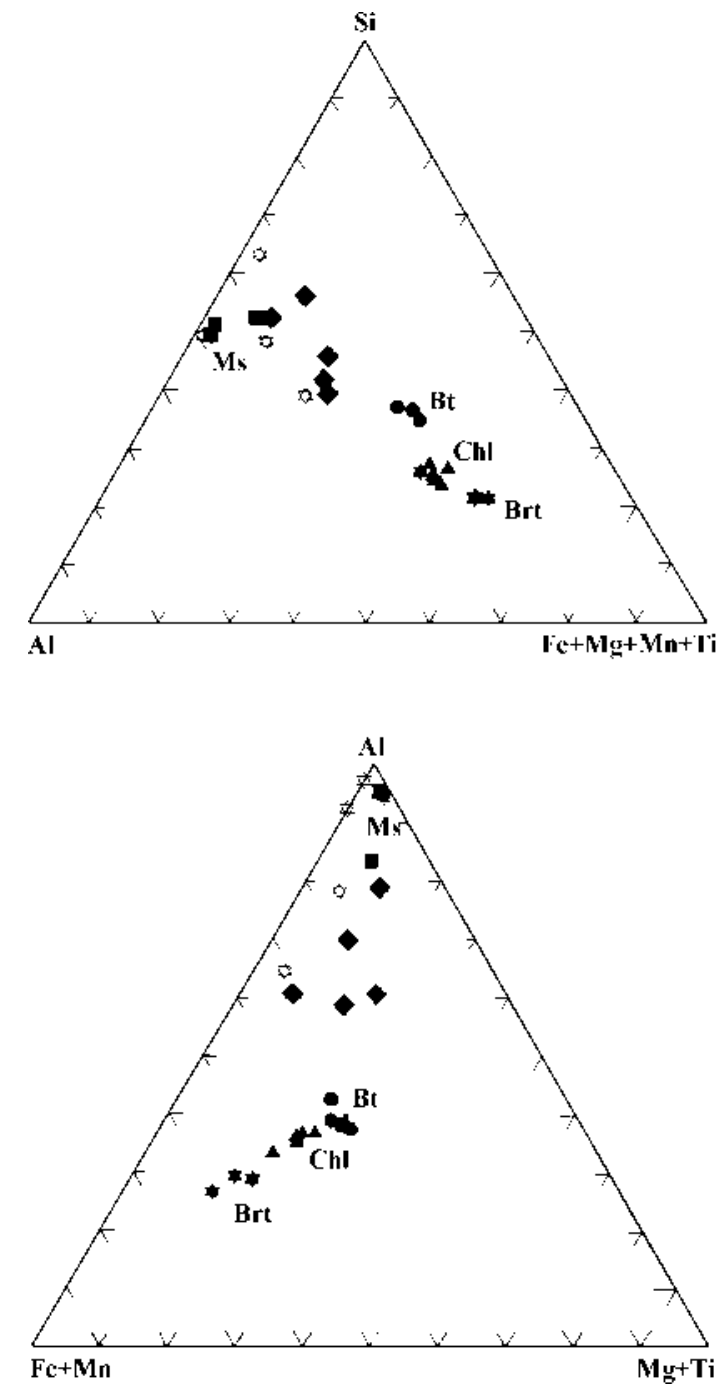

FIG. 13. Plot of the several phyllosilicate phases on the triangular diagrams $\mathrm{Si}-\mathrm{Al}-(\mathrm{Fe}$ $+\mathrm{Mg}+\mathrm{Mn}+\mathrm{Ti})(\mathrm{A})$ and $\mathrm{Al}-(\mathrm{Fe}+\mathrm{Mn})-(\mathrm{Mg}+\mathrm{Ti})(\mathrm{B})$. Full triangles: chlorite, full stars: berthierine, full circles: biotite, full squares: muscovite, full diamond: muscoviteberthierine intergrowths and mixed-layers, empty stars: "amorphous phases".

vor the preservation of signs of deformation of the preexisting Alpine chlorite. A similar mode of formation of berthierine from chlorite has been invoked as the main mechanism of formation by Slack et al. (1992). Chemical modifications of chlorite from spots, relative to chlorite from spot-free slates, include a decrease of $\mathrm{Si}$ and a slight enrichment in Fe (Tables 2,4). These modifications induce higher ${ }^{\mathrm{IV}} \mathrm{Al}$ contents, which probably represent re-equilibration of chlorite at a higher temperature (Cathelineau 1988). A similar trend is ob- served in berthierine compositions relative to chlorite. In this case, the strong decrease in $\mathrm{Si}$ is accompanied by notably higher Fe content and lower Al content. This chemical evolution has been represented in the triangular diagrams $\mathrm{Si}-\mathrm{Al}-(\mathrm{Fe}+\mathrm{Mg}+\mathrm{Mn}+\mathrm{Ti})$ and $\mathrm{Al}-$ $(\mathrm{Fe}+\mathrm{Mn})-(\mathrm{Mg}+\mathrm{Ti})($ Fig. 13)

The chemical changes described are also accompanied by structural modifications, such as the change from ordered polytypes of chlorite to polytypes with variable disorder in the stacking sequence. The struc- 
tural change from the chlorite to the berthierine structure is in most cases accompanied by important chemical variations. This fact suggests that the structural modifications occur as a consequence of the chemical changes associated with spot formation, the growth of the 7-Å structure of the berthierine being, in appearance, favored in microdomains where Fe content is higher. In this model, the disordered chlorite probably represents an intermediate phase in the transformation of ordered chlorite to berthierine.

Although most of the berthierine probably formed from chlorite, both the increase in the 7 - $\AA$ phase relative to mica in the concentrates of spots and the TEM images indicate that berthierine formation also involved muscovite. The high-resolution images reveal that most of the muscovite packets in contact with berthierine contain thin packets of berthierine. Moreover, muscovite and berthierine are interstratified in a wide range of relations, which are consistent with an intermediate stage of alteration from muscovite to berthierine, under non-equilibrium conditions. The formation of berthierine from muscovite during hydrothermal alteration has been considered as a probable mechanism by Slack $e t$ $a l$. (1992). Textural data indicate that berthierine formed from muscovite, but the possibility that both phases formed from a common precursor, e.g., from the breakdown of phengite in muscovite + berthierine, cannot be excluded.

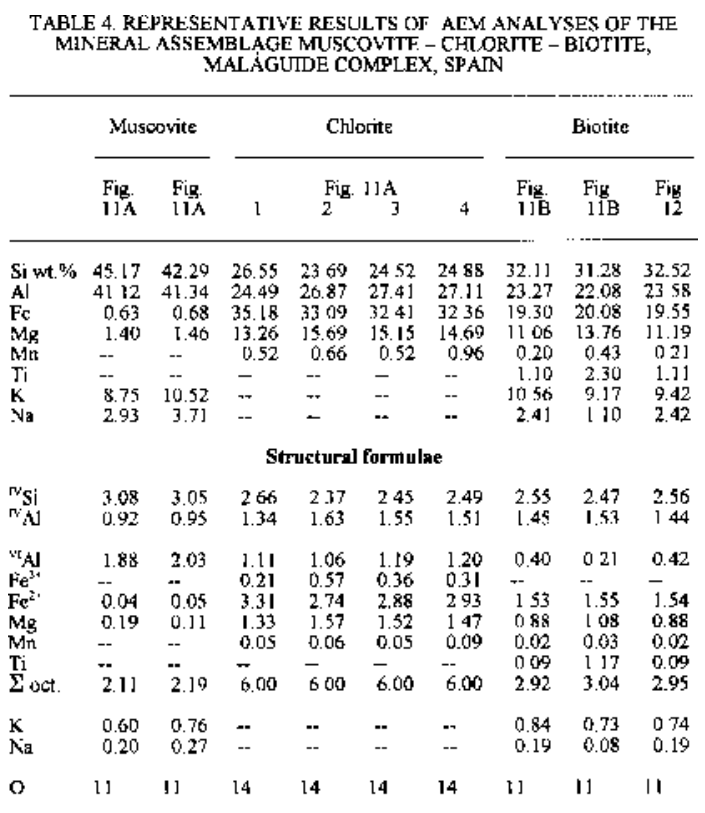

The normalization of muscomite and biotite formulae is based on charge balanoc relative to $] 1$ atoms of exygen. The semalization of shl orite composictions followed

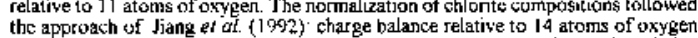

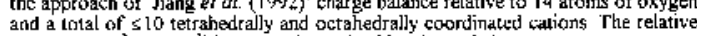

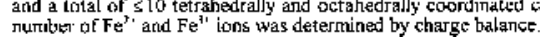

The formation of biotite by reaction of phengite and chlorite has been well characterized in low-grade metapelites (Guidotti 1984, Frey 1987). High-resolution images of biotite (Fig. 12) show 14- $\AA$ fringes, which suggests that most of the biotite formed from chlorite. At the same time, this reaction led to $(\mathrm{Fe}+\mathrm{Mg})$-free muscovite, with about $25 \%$ paragonite. Nevertheless, this reaction occurred to a lesser extent than that leading to berthierine. A comparison of berthierine and biotite compositions (Tables 3, 4, Fig. 13) reveals important differences in $\mathrm{Si}, \mathrm{Fe}$ and $\mathrm{Mg}$ content in the two phases, suggesting a chemical control in the formation of either berthierine or biotite.

Chemical modifications associated with spot formation appear to confirm this hypothesis. Thus in spots with a high $\mathrm{Fe}$ content, the association muscovite + berthierine is dominant (Figs. 2A, 4), whereas colorless spots with lower Fe content (Figs. 2C, D, 5) mainly contain the association muscovite + chlorite + biotite. Variable migration of $\mathrm{Fe}$ from the innermost zone of the spots toward the outer zones, and the parallel, inverse movement of $\mathrm{Al}$, are responsible for the observed zonation of minerals, and probably for the development either of biotite or berthierine.

The presence of berthierine in spots again poses the question of the stability field of this phase, which has been classically considered as a low-temperature polymorph of Fe-rich chlorite (Jiang et al. 1992, Xu \& Veblen 1996). It is clear from the AEM data that berthierine and chlorite cannot be considered as polymorphs in the rocks studied. This evidence supports the possibility of a true field of stability for berthierine in conditions of low-temperature thermal metamorphism. Nevertheless, the lack of equilibrium in the spots studied is indicated by the coexistence of several polytypes of chlorite together with berthierine in restricted microdomains (Jiang et al. 1992), as well as by the presence of "amorphous" phases, which could represent intermediate steps in the formation of andalusite and cordierite. The lack of equilibrium, probably caused by the high rate of heating, would also explain the formation of berthierine if this is a metastable phase. The absence of andalusite or cordierite in the spots indicates either that the temperatures required for their formation from a reaction of muscovite and chlorite (about $550^{\circ} \mathrm{C}$ ) were not attained or, more probably, that the rapid heating and cooling prevented the complete chemical rearrangement.

\section{Concluding Remarks}

Both textural features of the spots and chemical changes associated with spot formation indicate that the zoned spots formed during a prograde stage of thermal metamorphism, associated with the intrusion of dikes. The local formation of biotite indicates that the minimum temperature was above $400^{\circ} \mathrm{C}$. The chemical zonation and the presence of "amorphous" Al-rich phases 
also suggest that these spots represent an intermediate stage in the formation of andalusite or cordierite.

In the spots studied, the formation of berthierine appears to be related to two different processes, the transformation of the pre-existing chlorite and the replacement of muscovite. Textural and chemical lines of evidence indicate that the structure of berthierine is favored by the increase in Fe availability. Nevertheless, the non-equilibrium conditions, revealed by the coexistence of some chlorite polytypes and by the presence of "amorphous" phases, suggest that berthierine represents a metastable phase, developed during a brief event

\section{ACKNOWLEDGEMENTS}

The authors are grateful to K.J.T. Livi, an anonymous referee, and R.F. Martin, whose suggestions have notably improved the manuscript. We are also grateful to F. Nieto for discussions concerning interpretation of data and to M.M. Abad for help with the TEM-AEM data. This study has received financial support from the Project BTE-2000 1150 (Ministerio de Educación y Cultura) and from the Research Groups RNM 199 and 135 (Junta de Andalucía).

\section{REFERENCES}

Abad-Ortega, M. \& Nieto, F. (1995): Genetic and chemical relationships between berthierine, chlorite and cordierite in nodules associated to granitic pegmatites of Sierra Albarrana (Iberian Massif, Spain). Contrib. Mineral. Petrol. 120, 327-336.

Ahn, Jung-Ho \& Buseck, P.R. (1988): Al-chlorite as a hydration reaction product of andalusite: a new occurrence. Mineral. Mag. 52, 396-399.

Amouric, M., Gianetto, I. \& Proust, D. (1988): 7, 10 and 14 A mixed-layer phyllosilicates studied structurally by TEM in pelitic rocks of the Piemontese zone (Venezuela). Bull. Minéral. 111, 29-37.

BAILEY, S.W. (1980a): Structures of layer silicates. In Crystal Structures of Clay Minerals and their X-ray Identification (G.W. Brindley \& G. Brown, eds.). Mineralogical Society, London, U.K. (1-124).

(1980b): Summary of recommendations of AIPEA nomenclature committee on clay minerals. Am. Mineral. 65, 1-7.

(1988): Structures and composition of other trioctahedral 1:1 phyllosilicates. In Hydrous Phyllosilicates (Exclusive of Micas) (S.W. Bailey, ed.). Rev. Mineral. 19, 169-188.

Banfield, J.F., Karabinos, P. \& Veblen, D.R. (1989): Transmission electron microscopy of chloritoid: intergrowth with sheet silicates and reactions in metapelites. Am. Mineral. 74, 549-564.
BRINDLEY, G.W. (1982): Chemical composition of berthierines. A review. Clays Clay Minerals 30, 153-155.

Brown, G.\& Brindley, G.W. (1980): X-ray diffraction procedures for clay mineral identification. In Crystal Structures of Clay Minerals and their X-Ray Identification (G.W. Brindley \& G. Brown, eds.). Mineralogical Society, London, U.K. (305-359).

Bucher, K. \& Frey, M. (1994): Petrogenesis of Metamorphic Rocks. Springer-Verlag, Berlin, Germany.

Cathelineau, M. (1988): Cation site occupancy in chlorites and illites as a function of temperature. Clay Mineral. 23, 471-485.

Coombs, D.S., Zhao, G. \& Peacor, D.R. (2000): Manganoan berthierine, Meyers Pass, New Zealand: occurrence in the prehnite-pumpellyite facies. Mineral. Mag. 64, 1037-1046.

Curtis, C.D., Hughes, C.R., Whiteman, J.A. \& White, C.K. (1985): Compositional variation within some sedimentary chlorites and some comments on their origin. Mineral. Mag. 49, 375-386.

DeER, W.A., Howie, R.A. \& Zussman, J. (1976): Rock-Forming Minerals. 3. Sheet Silicates. Longman, London, U.K.

FreY, M. (1987): Very low-grade metamorphism of clastic sedimentary rocks. In Low Temperature Metamorphism (M. Frey, ed.). Blackie, Glasgow, U.K. (9-226).

GuidotTI, C.V. (1984): Micas in metamorphic rocks. In Micas (S.W. Bailey ed.). Rev. Mineral. 13, 357-457.

HARKER, A. (1939): Metamorphism. Chapman \& Hall, London, U.K.

Ijima, A. \& Matsumoto, R. (1982): Berthierine and chamosite in coal measures of Japan. Clays Clay Minerals 30, 264274.

Jiang, Wei-Teh, Peacor, D.R. \& Slack, J.F. (1992): Microstructures, mixed-layering and polymorphism of chlorite and retrograde berthierine in the Kidd Creek massive sulfide deposit, Ontario. Clays Clay Minerals 40, 501-514.

KERRICK, D.M. (1990): Crystal structures, optical and physical

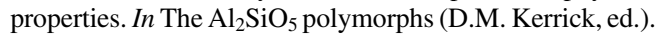
Rev. Mineral. 22, 13-35.

(1991): Overview of contact metamorphism. In Contact Metamorphism (D.M. Kerrick, ed.). Rev. Mineral. 26, 1-12.

KISCH, H.J. (1983): Mineralogy and petrology of burial diagenesis (burial metamorphism) and incipient metamorphism in clastic rocks. In Diagenesis in Sediments and Sedimentary Rocks 2 (G. Larsen \& G.V. Chilingar, eds.). Elsevier, New York, N.Y. (289-493).

KRETZ, R. (1983): Symbols for rock-forming minerals. Am. Mineral. 68, 277-279. 
LORIMER, G.W. \& ClifF, G. (1976): Analytical electron microscopy of minerals. In Electron Microscopy in Mineralogy (H.R. Wenk et al., ed.). Springer-Verlag, New York, N.Y. (506-519).

MäKEL, G.H. (1985): The geology of the Maláguide Complex and its bearing on the geodynamic evolution of the BeticRif orogen (southern Spain and northern Morocco). GUA Papers of Geology, Ser. 1, 22.

MiYashiRo, A. (1994): Metamorphic Petrology. UCL Press, London, U.K.

PATtison, D.R.M. \& TRACY, R.J. (1991): Phase equilibria and thermobarometry of metapelites. In Contact Metamorphism (D.M. Kerrick, ed.). Rev. Mineral. 26, 105-206.

RuIz CRUZ, M.D. (1996): Dickite, nacrite, and possible dickite/ nacrite mixed-layers from the Betic Cordilleras (Spain). Clays Clay Minerals 44, 357-369.

(1997): Very low-grade chlorite with anomalous chemistry and optical properties from the Maláguide Complex (Betic Cordilleras, Spain). Can. Mineral. 35, 923 935.

(1999): New data for metamorphic vermiculite. Eur. J. Mineral. 11, 533-548.

(2001): Mixed-layers mica-chlorite in very lowgrade metaclastites from the Maláguide Complex (Betic Cordilleras, Spain). Clay Minerals 36, 307-324.

\& ANDREO, B. (1996a): Genesis and transformation of dickite in Permo-Triassic sediments (Betic Cordilleras, Spain). Clay Minerals 31, 133-152.

$\&$ (1996b): Tosudite in very low-grade metamorphic graywackes from the Málaga area (Betic Cordilleras, Spain). Eur. J. Mineral. 8, 1391-1399.

\& Moreno Real, L. (1996): Dehydroxylation of Ferich chlorite. Geol. Carpathica, Clays 5, 65-71.

\& RodRÍGUEZ JiMÉNEZ, P. (2002): Correlation between crystallochemical parameters of phyllosilicates and mineral facies in very low-grade rocks of the Betic Cordillera (Spain). Clay Minerals 37, 169-185.

Slack, J.F., Jiang, Wei-Teh, Peacor, D.R. \& Okita, P.M. (1992): Hydrothermal and metamorphic berthierine from the Kidd Creek volcanogenic massive sulfide deposit, Timmins, Ontario, Can. Mineral. 30, 1127-1142.

Torres-Roldán, R.L., Poli, G. \& Peccerillo, A. (1986): An Early Miocene arc-tholeiitic magmatic dike event from Alboran-Sea. Evidence for precollisional subduction and back-arc crustal extension in the westernmost Mediterranean. Geol. Rund. 75, 219-234.

Toth, T.A. \& FrITZ, S.J. (1997): An Fe-berthierine from a Cretaceous laterite. I. Characterization. Clays Clay Minerals 45, 564-579.

Velde, B. (1973): Phase equilibria studies in the system MgO$\mathrm{Al}_{2} \mathrm{O}_{3}-\mathrm{SiO}_{2}-\mathrm{H}_{2} \mathrm{O}$ : chlorite and associated minerals. Mineral. Mag. 39, 297-312.

WALKER, J.R. \& THOMPSON, G.R. (1990): Structural variations in chlorite and illite in a diagenetic sequence from the Imperial Valley, California. Clays Clay Minerals 38, 315321.

Weaver, C.E. (1989): Clays, Muds and Shales. Elsevier, Amsterdam, The Netherlands.

WEISS, Z. (1991): Interpretation of chemical composition and X-ray diffraction patterns of chlorites. Geol. Carpathica 42, 93-104.

Xu, Huifang \& Veblen, D.R. (1996): Interstratification and other reaction microstructures in the chlorite-berthierine series. Contrib. Mineral. Petrol. 124, 291-301.

YARDLEY, B.W.D. (1989): An Introduction To Metamorphic Petrology. Longman Sci. and Tech., London, U.K. (60-90).

Received March 11, 2002, revised manuscript accepted July 15, 2002. 